\title{
Versatile Ruthenium Complex "RuPCY” for Directed Catalytic Hydrogen Management in Organic Synthesis
}

\author{
Yuki Takada, Megumi Iida, Kazuki Iida, Takashi Miura, and Susumu Saito* \\ Graduate School of Science, Nagoya University \\ Chikusa, Nagoya 464-8602, Japan
}

(Received July 1, 2016; E-mail: saito.susumu@f.mbox.nagoya-u.ac.jp)

\begin{abstract}
The ruthenium (Ru) precatalyst complex dichlorobis[2-[(dicyclohexylphosphino- $\kappa \mathrm{P})$ methyl]pyridine $-\kappa$ N]ruthenium(II) (RuPCY), first developed by us, was shown to be useful not only for the catalytic hydrogenation of inert carboxylic acid derivatives including amides and esters, but also for the catalytic dehydrogenation of primary $\left(1^{\circ}\right)$ and secondary $\left(2^{\circ}\right)$ alcohols and subsequent reactions. RuPCY is versatile, and different $\mathrm{Ru}$ catalysts derived therefrom are quite useful for realizing a variety of indiscrete/discrete catalytic hydrogen management (HyMA) reactions. The sequential use of different starting materials and different catalysts (all derived from RuPCY) permits otherwise challenging orthogonal HyMA processes. This accommodates, for example, a salt-free access and/or shortcut to synthetic intermediates of pharmaceutically important substances such as donepezil (Aricept ${ }^{\circledR}$ ) and atorvastatin (Lipitor ${ }^{\circledR}$ ).
\end{abstract}

\section{Introduction}

Hydrogenation and dehydrogenation are extremely useful for both industrial processes and laboratory experiments. ${ }^{1}$ Hydrogenation of carbonyl compounds and dehydrogenation of alcohols (Figure 1a) are, in principle, a set of complementary reversible hydrogen transfer (HT) processes following an identical reaction coordinate. ${ }^{2}$ HT involves the absorption/ desorption of $\mathrm{H}_{2}, 1$ equivalent per reactant, in which two hydrogen atoms are sequentially incorporated into/removed from the carbon-oxygen framework. Among representative synthetic applications, asymmetric hydrogenation of ketones has been well established by Noyori and others. ${ }^{3} 2^{\circ}$ alcoholketone interconversion is promoted by transition metal catalysts, ${ }^{2 \mathrm{~b}-\mathrm{d}, 4}$ and chiral variants afford asymmetric versions of the dehydrogenation reactions. ${ }^{5}$ Dehydrogenation of $1^{\circ}$ alcohols can also be followed by crossed aldol condensation of the resulting aldehydes with ketones, ${ }^{6}$ esters, ${ }^{7}$ and amides ${ }^{8}$ giving $\alpha, \beta$-unsaturated carbonyl compounds, and subsequent (transfer) hydrogenation of the ene part gives $\alpha$-alkylated carbonyl compounds (Figure $1 \mathrm{a} \rightarrow 1 \mathrm{~b}$ ).

In contrast, HTs involving effectively 2 equivalents of $\mathrm{H}_{2}$ (four hydrogen atoms) are mechanistically more intricate (Figure $1 \mathrm{a} \rightarrow 1 \mathrm{c}, 1 \mathrm{c}^{\prime} \rightarrow 1 \mathrm{a}$, and $1 \mathrm{a} \rightarrow 1 \mathrm{~b} \rightarrow 1 \mathrm{~d}$ ). These catalyst systems are exemplified by the hydrogenation of an ester, ${ }^{1 \mathrm{a}-\mathrm{e}, 9}$ ${\text { carboxylic } \text { acid }^{10} \text { or amide }}^{\mathrm{lb}-\mathrm{e}, 11}$ (Figure $1 \mathrm{c}^{\prime} \rightarrow 1 \mathrm{a}^{\prime}$ ). Two discrete hydrogenation steps (Figure 1c' and 1a') are involved during the three-step sequence consisting of: 1) hydrogen addition to the $\mathrm{X}(\mathrm{C}=\mathrm{O}) \mathrm{R}$ group (ester, carboxylic acid, or amide); 2$) \beta$ elimination of $\mathrm{XH}$ or $\mathrm{H}_{2} \mathrm{O}$; and 3) hydrogen addition to the $\mathrm{H}(\mathrm{C}=\mathrm{O}) \mathrm{R}$ or $\mathrm{H}(\mathrm{C}=\mathrm{N}) \mathrm{R}$ group. The reverse processes, namely intermolecular dehydrogenative alcohol-alcohol, ${ }^{\text {a }, \mathrm{b}, 2 \mathrm{c}, 4 \mathrm{~d}, 9 \mathrm{e}, \mathrm{r}, 12}$ alcohol- $\mathrm{H}_{2} \mathrm{O},{ }^{13}$ and amine-alcohol ${ }^{1 \mathrm{~b}, \mathrm{f}, 11 \mathrm{e}, \mathrm{g}, 12 \mathrm{c}, \mathrm{g}, \mathrm{i}, 14}$ coupling reactions (giving esters, carboxylic acid, and amides, respectively; Figure $1 \mathrm{a} \rightarrow 1 \mathrm{c}$ ), have also been well investigated. On occasions where two or more alcohol molecules are involved in the coupling reaction, dehydrogenation of an alcohol is followed either by dehydrative dialkyl acetal formation, ${ }^{15}$ or by dehydrative carbon-carbon bond formation through aldol condensation with a carbonyl compound derived by dehydrogenation of

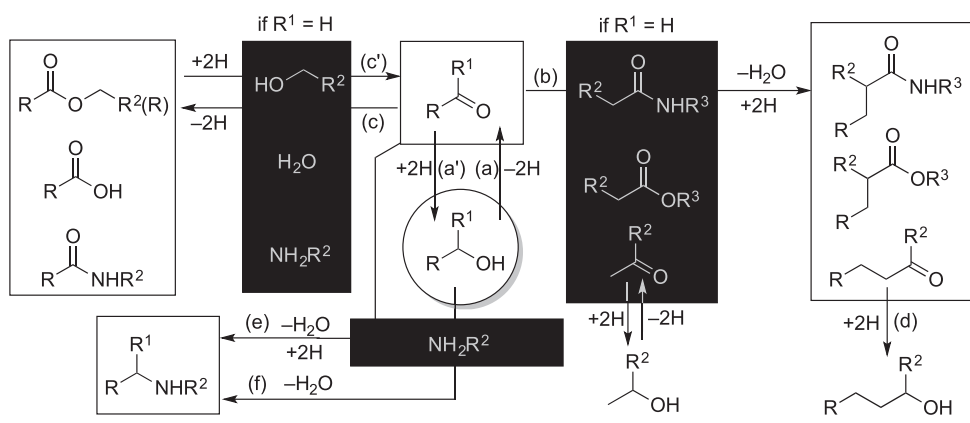

Figure 1. $1^{\circ}$ (when $\mathrm{R}^{1}=\mathrm{H}$ ) and $2^{\circ}$ (when $\mathrm{R}^{1}=$ any carbon chains) alcohols in center of multifaceted hydrogen transfer (HT) processes in strategic hydrogen management (HyMA) for: (a) dehydrogenation of alcohol and (a') the reverse; (b) aldol condensation/ene hydrogenation of $\alpha, \beta$ unsaturated carbonyl compound, giving $\alpha$-alkylation; (c) dehydrogenative synthesis of carboxylic acid and its derivatives and (c') the reverse; (d) "post (b)" reaction: ketone hydrogenation; (e) "post (a)" reaction: dehydration/hydrogenative $\mathrm{N}$-alkylation; (f) dehydrative $\mathrm{N}$ alkylation. 

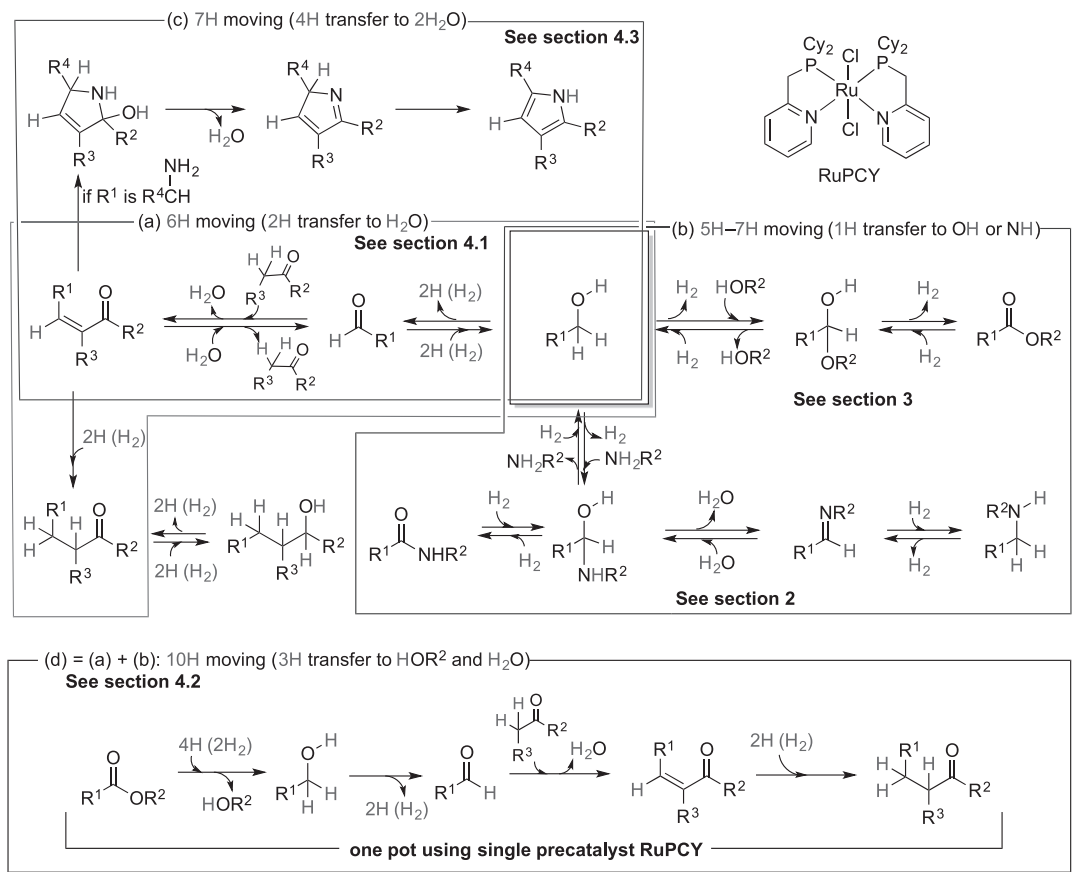

Figure 2. Our studies on multifaceted hydrogen management (HyMA) in virtually "saltfree” organic synthesis. Reactions in lines are promoted by RuPCY. (a) alcohol in $\alpha$-alkylation of ketone; (b) alcohol formation by hydrogenation of amide and ester; (c) $\beta$-amino alcohol in $\alpha$-alkylation of ketone and imine formation for pyrrole synthesis; (d) alcohol generated by ester hydrogenation for $\alpha^{-}$ alkylation of ketone that leads to donepezil.

the other alcohol and subsequent (transfer) hydrogenation of the ene and carbonyl groups, giving carbon-elongated saturated alcohols (Guerbet-type reaction) (Figure $1 \mathrm{a} \rightarrow 1 \mathrm{~b} \rightarrow 1 \mathrm{~d}$ ). ${ }^{16}$

In the presence of an amine, dehydrogenation of the alcohol followed by dehydrative reaction with the amine produces an imine, after which the reaction ceases, ${ }^{17}$ or further (transfer) hydrogenation of the $\mathrm{C}=\mathrm{N}$ bond affords $\mathrm{N}$-alkylation, giving an amine $\mathrm{e}^{2 \mathrm{~h}, 14 \mathrm{~d}, 18}$ (Figure $1 \mathrm{a} \rightarrow 1 \mathrm{e}$ ). Our group previously reported exceptional $\mathrm{N}$-alkylation with $1^{\circ}, 2^{\circ}$, and tertiary $\left(3^{\circ}\right)$ alcohols, where only dehydration, in the absence of dehydrogenation, was involved (Figure 1f). ${ }^{19}$ This dehydration took place merely as a consequence of (mainly $\mathrm{S}_{\mathrm{N}} 2$ ) substitution of the alcoholic carbon by the amine nitrogen. In contrast, allylic alcohols are converted into $\pi$-allyl metal complexes and frequently used as $\mathrm{N}$-allylating agents. ${ }^{19 \mathrm{e}-\mathrm{i}}$

In each reaction, specific $\mathrm{Z}-\mathrm{H}(\mathrm{Z}=\mathrm{H}, \mathrm{C}, \mathrm{N}$ or $\mathrm{O})$ bonds are cleaved, accompanied by subsequent $\mathrm{C}-\mathrm{Z}(\mathrm{Z}=\mathrm{H}, \mathrm{C}, \mathrm{N}$ or $\mathrm{O})$ bond formation without producing salt wastes (Figure 1a-1f). Alcohol is in center of hydrogen management (HyMA), working not only as a reactant, but also as a hydrogen shuttle/ hydrogen storage. Thus catalytic HyMA can control great diversity in bond cleavage and formation involving various HT reactions (many involving alcohols) by altering the behavior and movement of hydrogen atoms (e.g., $\mathrm{H}^{+}, \mathrm{H}^{-}, \mathrm{H}^{*}, \mathrm{H}^{+}+\mathrm{e}^{-}$), abstracted from $\mathrm{H}-\mathrm{H}, \mathrm{C}-\mathrm{H}, \mathrm{N}-\mathrm{H}$, and $\mathrm{O}-\mathrm{H}$ bonds. Overall scenario depicted in Figure 1 clearly indicates that the hydrogens generated in HyMA are incorporated into desirable product(s) including $\mathrm{H}_{2}(2 \mathrm{H})$ and/or $\mathrm{H}_{2} \mathrm{O}$ (as a byproduct), and are not transferred to an inorganic/organic base for neutralization, forming salt waste/byproducts. Each HT step involves a distinct mechanism, and thus, each HT may require a specialty transition metal catalyst developed separately. Thus, directed assembly of an HT catalyst pool using the same precatalyst to achieve an intricate array of HyMA strategies to allow complementary $\mathrm{Z}-\mathrm{H}$ bond cleavage and $\mathrm{C}-\mathrm{Z}$ bond formation in one-pot, is a significant challenge and a desirable goal. The ruthenium precatalyst complex "RuPCY" (PCY=PhosphinatodiCYclohexyl), can discretely catalyze a variety of HT reactions including hydrogenation of amides ${ }^{20}$ and esters, ${ }^{21}$ as well as dehydrogenation of $1^{\circ}$ and $2^{\circ}$ alcohols ${ }^{22}$ and subsequent carbon-carbon bond-forming reactions (Figure 2). In addition, RuPCY is versatile in maintaining the consecutive nature of a multistep HyMA catalysis such that different reactants (e.g., ester, $\mathrm{H}_{2}$, alcohol, ketone, olefin) can, in turn, undergo multifaceted HTs in one pot. One example of the overall sequence can be represented by: i) hydrogenation of ester giving alcohol; ii) transfer dehydrogenation of the alcohol giving the aldehyde or ketone; iii) crossed aldol condensation of the resulting carbonyl compound with a second ketone giving an $\alpha, \beta$-unsaturated ketone; and iv) transfer hydrogenation of the olefin of the $\alpha, \beta$-unsaturated ketone giving the saturated ketone. These four steps can be applied for an atom- and step-economical one-pot synthesis of donepezil ( $\mathrm{HCl}$ salt: Aricept $\left.{ }^{\circledR}\right) .{ }^{21}$ The core pyrrole structure of Lipitor ${ }^{\circledR}$ is similarly accessible, as it is synthesized via a set of different HT reactions. $^{22}$

\section{Hydrogenation of Unactivated Amides}

Amides are ubiquitous and abundant in nature and our society. For example, they could be found in the repeating units of polypeptide macromolecules and artificial polymeric materials (e.g., poly(acrylamide), nylons, Kevlar), and their respective monomers (e.g., $\alpha, \beta$-unsaturated carboxamides, caprolactams), which can be produced on an enormous scale via existing industrial processes. They also exist as potent pharmacophores, ${ }^{9 t, 23}$ which are useful building blocks accessible via many 
synthetic methods. ${ }^{24}$ Were it possible to develop catalytic transformations of amide resources without the salt-containing wastes formed in stoichiometric amounts with respect to the amide, such chemical processes would provide a shortcut or alternative route to presently known and/or unknown materials or chemicals. However, amides are very stable and reluctant to salt-free, catalytic chemical transformations, which are significantly challenging, as there is a lack of basic knowledge concerning the catalytic activation. As a part of our continuous research on the catalytic transformation and functionalization of amides (AD), ${ }^{25}$ we recently found a more general method than precedents, ${ }^{1 \mathrm{~b}-\mathrm{e}, 11}$ for the hydrogenation of unactivated amides, affording selective $\mathrm{C}-\mathrm{N}$ or $\mathrm{C}=\mathrm{O}$ bond cleavage using a new Ru complex RuPCY. ${ }^{20}$

Treatment of a toluene solution of AD-a and RuPCY ( $2 \mathrm{~mol} \%$ ) with sterically bulky base BS-a (20 mol \%) under hydrogen pressure $\left(P_{\mathrm{H} 2}\right)$ of $8 \mathrm{MPa}$ at reaction temperature $(T)$ of $160{ }^{\circ} \mathrm{C}$ for reaction time $(t)$ of $24 \mathrm{~h}$ gave the corresponding alcohol (AL) and amine (AM), AL-a and AM-a, in $92 \%$ yield (eq. 1). The steric bulkiness of the base was more important than its basicity under similar conditions $\left([\mathrm{Ru}]_{0}=6.7 \mathrm{mM} ; P_{\mathrm{H} 2}\right.$ $=6 \mathrm{MPa}, 160{ }^{\circ} \mathrm{C}, 48 \mathrm{~h}$ ): use of phenoxide BS-b in place of BSa gave $\mathrm{AL}-\mathbf{a}$ with similar effectiveness ( $\mathrm{AL}-\mathbf{a}$ : $94 \%, \mathrm{AM}-\mathbf{a}$ : $86 \%$ ). Smaller bases including $\mathrm{NaO} t \mathrm{Bu}, \mathrm{KO} t \mathrm{Bu}, \mathrm{NaOMe}$ and $\mathrm{NaOH}$ gave lower productivity ( $\mathrm{AL}-\mathbf{a}: 2-43 \%$ ). According to control experiments using smaller RuPCY derivatives, the combined use of RuPCY and a base additive such as BS-a or BS-b, both being sterically demanding, is crucial for selective hydrogenation.

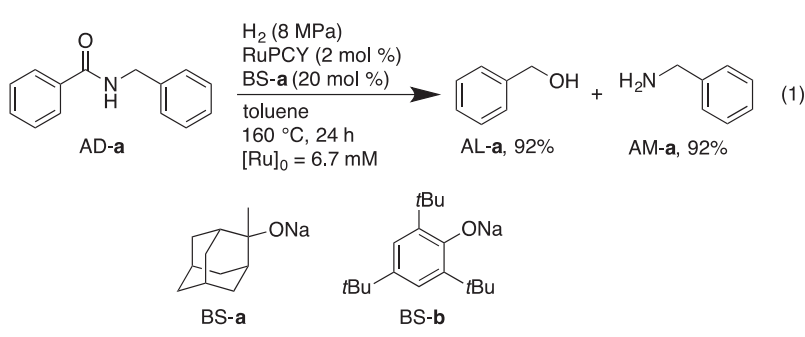

This hydrogenation method was selective (i.e., negligible dearomatization) and showed wider substrate scope with respect to unactivated amides. Selective $\mathrm{C}-\mathrm{N}$ bond cleavage of linear amides was uniformly observed (eqs 2-8). ${ }^{11 \mathrm{i}} 1^{\circ}$ and $3^{\circ}$ amides $\mathrm{AD}-\mathbf{b}$ and $\mathrm{AD}-\mathbf{c}$, and simple aliphatic $2^{\circ}$ amides $\mathrm{AD}^{-}$ d and $\mathrm{AD}-\mathbf{e}$, were also applicable substrates. The active species maintained its catalytic integrity even after a lengthy reaction time in the hydrogenation of $1^{\circ}$ amide AD-b (eq. 2), but marginal hydrogenation took place with more bulky AD-f (eq. 6).

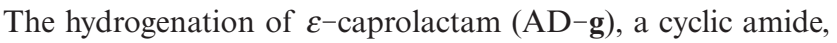
which serves as the monomer of nylon-6, showed a similar pattern of bond cleavage (eq. 7). Hydrogenation was rather sluggish with $\mathrm{AD}-\mathbf{h}$ derived by $\mathrm{N}$-methylation of $\mathrm{AD}-\mathbf{g}$ (eq. 7). Product AA-g and AA-h could be a synthetic precursor of $N, N$-dimethyl-6-amino-1-hexanol, a polymerization initiator. $^{26}$

Hydrogenation of urea ${ }^{11--9} \mathrm{AD}-\mathbf{i}$ is important with respect to the methanol economy, ${ }^{27}$ since ureas are excellent chemical reservoirs and carriers of $\mathrm{CO}_{2}$ (eq. 8). However, a larger amount of base $(20 \mathrm{~mol} \%)$ only ensured a reasonable reaction rate for the more inert aliphatic amides.

In contrast, $\mathrm{C}=\mathrm{O}$ bond cleavage predominated with five- and six-membered lactams $\mathrm{AD}-\mathbf{j}$ and $\mathrm{AD}-\mathbf{k}$ (eq. 9). This apparent $\mathrm{C}=\mathrm{O}$ bond scission can be explained by a multistep HyMA sequence consisted of hydrogenative $\mathrm{C}-\mathrm{N}$ bond cleavage of the amides giving $\mathrm{NH}_{2}\left(\mathrm{CH}_{2}\right)_{\mathrm{n}} \mathrm{OH}$, followed by oxidation of the $\mathrm{HOCH}_{2}-$ group giving $\mathrm{NH}_{2}\left(\mathrm{CH}_{2}\right)_{\mathrm{n}-1} \mathrm{CHO}$, then intramolecular imine formation, and finally, imine hydrogenation (Figure 3). In fact, when AA-k was used as the starting material in the absence of $\mathrm{H}_{2}$ or with $P_{\mathrm{H} 2}=8 \mathrm{MPa}$ under otherwise identical conditions $\left(T=160{ }^{\circ} \mathrm{C}, t=24 \mathrm{~h}\right)$, amide AD-k and piperidine (AM-k) were obtained in $53 \%$ and $25 \%$, and $28 \%$ and $48 \%$ yields, respectively.

Hydrogenation was generally sluggish $(t>24 \mathrm{~h})$ and
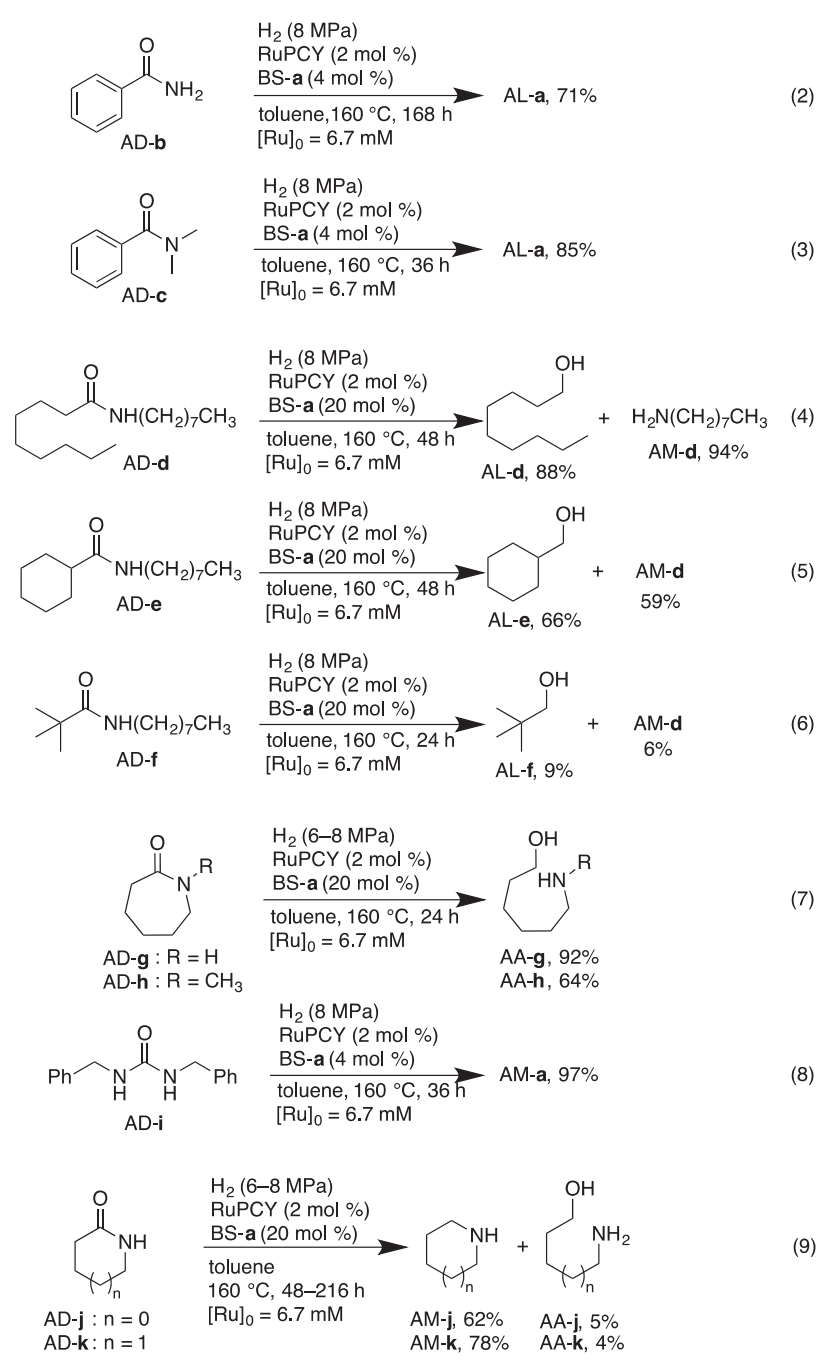
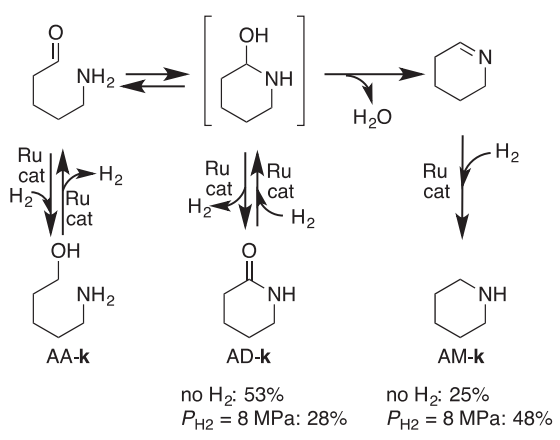

Figure 3. Control experiments using AA-k in the presence or absence of $\mathrm{H}_{2}$. 
required harsh reaction conditions. A high temperature and a high $P_{\mathrm{H} 2}$ may be required either to produce a catalytic species from RuPCY, or for the hydrogenation of amide. To probe this speculation, BS-a (4 mol \%) was exposed to a toluene solution of RuPCY ( $2 \mathrm{~mol} \%)$ in the absence of amide (e.g., AD-a) for preactivation of the catalyst $\left(P_{\mathrm{H} 2}=8 \mathrm{MPa}, T=160{ }^{\circ} \mathrm{C}, t=5 \mathrm{~h}\right)$, and the resulting matured catalyst was used for the hydrogenation of $\mathrm{AD}-\mathbf{a}$ under milder conditions with a shortened $t\left(P_{\mathrm{H} 2}\right.$ $\left.=4 \mathrm{MPa}, T=140{ }^{\circ} \mathrm{C}, t=12 \mathrm{~h}\right)$. Indeed, AL-a and AM-a were produced in $89 \%$ and $89 \%$ yields, respectively. When even milder conditions were used for the hydrogenation of $\mathrm{AD}-\mathbf{a}$ $\left(P_{\mathrm{H} 2}=2 \mathrm{MPa}, T=120{ }^{\circ} \mathrm{C}\right)$ using the preactivated catalyst, a high yield of $\mathrm{AL}-\mathbf{a}(93 \%)$ and $\mathrm{AM}-\mathbf{a}(92 \%)$ was still obtained by prolonging the reaction time to $60 \mathrm{~h}$.

What would be the structural change of RuPCY that occurs during the induction period of catalyst under a high temperature and a high $P_{\mathrm{H} 2}$ ? To clarify this, the ${ }^{31} \mathrm{P}\left\{{ }^{1} \mathrm{H}\right\} \mathrm{NMR}$ (toluene- $d_{8}$ ) spectrum of the reaction mixture obtained after a period of the optimal preactivation (vide infra) showed a major singlet at $\delta-15.2 \mathrm{ppm}$ corresponding to saturated amino phosphine $\mathrm{AP}-\mathbf{a}$. In order to further confirm the identity of the catalytic species involving $\mathrm{AP}-\mathbf{a}$, the reaction mixture was quenched with excess $\mathrm{BH}_{3} \cdot \mathrm{THF}$ and was analyzed via electrospray ionization mass spectroscopy. The base peak obtained matched fully saturated $\mathrm{AP}-\mathbf{a}$ complexed with $\mathrm{BH}_{3}$. The mercury test ${ }^{28}$ was also employed, in which $\mathrm{Hg}(0)$ was added during the hydrogenation step to probe the possibility of catalysis by a $\mathrm{Ru}$ nanoparticle. The catalytic activity was not perturbed during the course of the reaction (AL-a: 94\%; AM-a: 92\%). All these control experiments suggest that either RuPCY $-h_{16}$ or RuPCY $-h_{8}$ would be a resting state of the catalyst (Figure 4). In any event, hydrogenative HyMA was involved in reduction of the interior structural part of precatalyst RuPCY during induction period of catalyst.

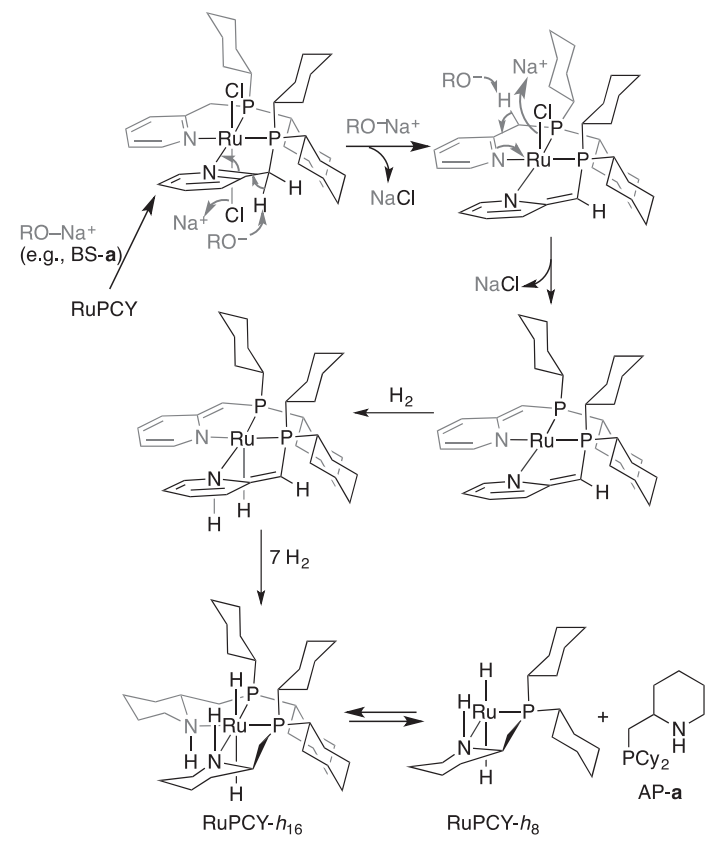

Figure 4. Proposed mechanism "multi-hydrogenation" of RuPCY involved behind catalyst preactivation.

\section{Hydrogenation of Esters}

Since catalytic RuPCY and alkoxide base BS-a was proven to be effective for the hydrogenation of unactivated amides ( $P_{\mathrm{H} 2}=2-8 \mathrm{MPa}, \quad T=120-160{ }^{\circ} \mathrm{C}$, toluene), these optimized amide hydrogenation conditions were also used for the hydrogenation of esters (ES). The hydrogenation of methyl benzoate (ES-a) took place, however, sluggishly. Use of catalytic $\mathrm{NaBH}_{4}$ and THF in place of $\mathrm{BS}-\mathbf{a}$ and toluene was more promising. Hydrogenation of ES-a gave $\mathrm{AL}-\mathbf{a}$ quantitatively $\left(P_{\mathrm{H} 2}\right.$ $=6 \mathrm{MPa}, T=160{ }^{\circ} \mathrm{C}, t=24 \mathrm{~h} ;[\mathrm{Ru}]_{0}=3.3 \mathrm{mM}$ : RuPCY $(1 \mathrm{~mol} \%)$ in $\left.\mathrm{THF}, \mathrm{NaBH}_{4}(10 \mathrm{~mol} \%)\right)$. The $\mathrm{Hg}(0)$ test $^{28}$ was again employed, in which the catalytic activity was not perturbed (AL-a: 94\%), excluding the possibility of catalysis by a Ru nanoparticle. In addition to the methyl ester, ethyl- (Et-), isopropyl- $(i \mathrm{Pr}-)$, benzyl- $\left(\mathrm{Bn}^{-}\right)$and phenyl $(\mathrm{Ph})$ benzoates underwent effective hydrogenation under otherwise identical reaction conditions, consistently giving $\mathrm{AL}-\mathbf{a}$ in near quantitative yields $(94-99 \%)$. In contrast, hydrogenation of tert-butyl $(t \mathrm{Bu})$ benzoate was very ineffective (AL-a: $4 \%)$. The hydrogenation of ES-a was mildly affected by $P_{\mathrm{H} 2}$ (Figure 5a), and proceeded even under $P_{\mathrm{H} 2}=1 \mathrm{MPa}$, albeit with a decline in reaction rate of nearly one half from that observed under $P_{\mathrm{H} 2}$ $=3 \mathrm{MPa}$. In contrast, the hydrogenation rate was significantly affected by $T$ (Figure $5 b$ ).

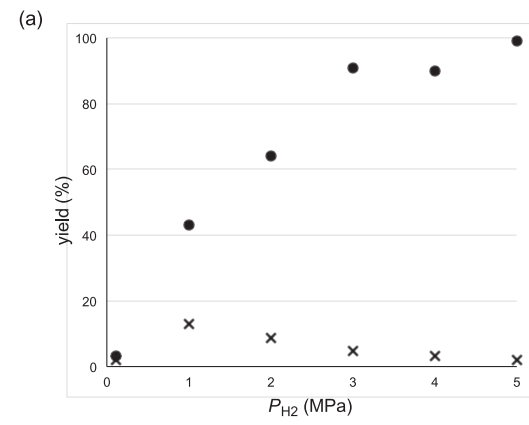

(b)

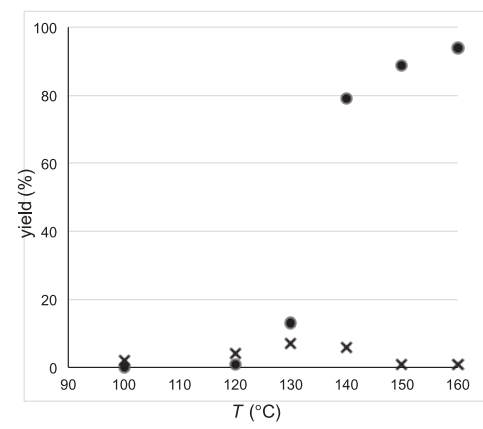

Figure 5. Effects of: (a) $P_{\mathrm{H} 2}(\mathrm{MPa})$ at $160{ }^{\circ} \mathrm{C}$; and (b) $T\left({ }^{\circ} \mathrm{C}\right)$ at $P_{\mathrm{H} 2}$ $=6 \mathrm{MPa}$ on yields $(\%)$ of AL-a (filled circle) and ES-aa (cross) in hydrogenation of ES-a. Reaction time $(t)=12 \mathrm{~h}$; $[\mathrm{Ru}]_{0}=3.3 \mathrm{mM}\left(\mathrm{RuPCY}(1 \mathrm{~mol} \%)\right.$ in THF); $\mathrm{NaBH}_{4}$ (10 $\mathrm{mol} \%$ ).

A temperature of at least $140{ }^{\circ} \mathrm{C}$ was critical in order to maintain fair to excellent catalytic activity, and the rate dropped significantly at $130{ }^{\circ} \mathrm{C}$ and below. Hydrogenation of ES-a was faster with $[\mathrm{Ru}]_{0}=10 \mathrm{mM}$ than with $[\mathrm{Ru}]_{0}=3.3 \mathrm{mM}$. Under the most expedient conditions $\left(P_{\mathrm{H} 2}=6 \mathrm{MPa} ; T=160{ }^{\circ} \mathrm{C}\right.$; $[\mathrm{Ru}]_{0}=10 \mathrm{mM}$ ), the induction period of catalyst (preactivation period) was ca. $2 \mathrm{~h}$, with a total reaction time of $4-5 \mathrm{~h}$ for full conversion of ES-a. During preactivation, alcohols $\mathrm{CH}_{3} \mathrm{OH}$ 
and $\mathrm{AL}-\mathbf{a}(\mathrm{BnOH})$ were gradually generated as the hydrogenation proceeded, and concomitantly, the reaction rate sped up. It was therefore envisaged that added alcohol would have some effect on accelerating the catalyst preactivation. Indeed, when the hydrogenation of ES-a was initiated in the presence of catalytic $\mathrm{AL}-\mathbf{a}(2 \mathrm{~mol} \%)$, the original preactivation period of ca. $2 \mathrm{~h}$ was significantly shortened to $<20 \mathrm{~min}$ (Figures 6 and 7). Thus, to best affect the preactivation, an appropriate amount of $\mathrm{AL}-\mathbf{a}$ should be added before starting the hydrogenation of ES. This addition of an alcohol to shorten the induction period of catalyst is a new strategy in the development of catalysts promoting ester hydrogenation.

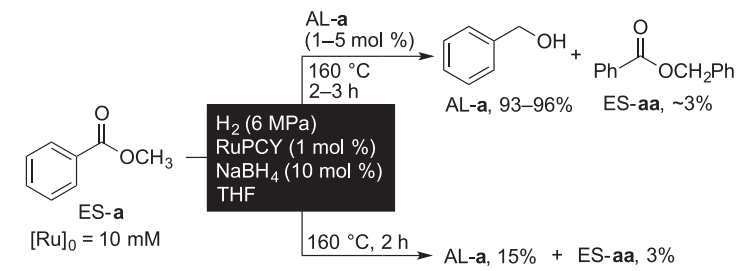

Figure 6. Effects of catalytic $\mathrm{BnOH}$ on hydrogenation of ES-a.

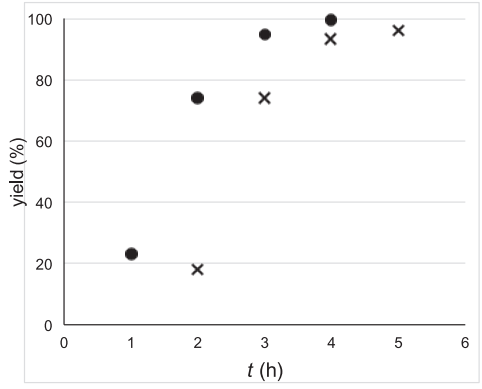

Figure 7. Effects of catalytic alcohol on $t$-dependent yield (\%) of $\mathrm{AL}-\mathbf{a}$ with: $\mathrm{AL}-\mathbf{a}(2 \mathrm{~mol} \%)$ (filled circle); and without $\mathrm{BnOH}$ (cross) in hydrogenation of $\mathrm{ES}-\mathbf{a} . P_{\mathrm{H} 2}=6 \mathrm{MPa}$, $T=160{ }^{\circ} \mathrm{C} ;[\mathrm{Ru}]_{0}=10 \mathrm{mM}(\operatorname{RuPCY}(1 \mathrm{~mol} \%)$ in THF); $\mathrm{NaBH}_{4}(10 \mathrm{~mol} \%)$.

The ester was switched from aromatic ES-a to aliphatic ES-b, and several parameters that affect the hydrogenation rate were investigated (Figure 8). The effect of alcohol identity on preactivation was explored, and other alcohols including EtOH (and $i \mathrm{PrOH}$ ) had a similar but less efficient effect (eq. 10). All reactions shown here were thus carried out with a catalytic amount of $\mathrm{AL}-\mathbf{a}$. Hydrogenation took place reason-

\begin{tabular}{|c|c|c|c|c|c|}
\hline \multirow{2}{*}{\multicolumn{2}{|c|}{$\underbrace{\mathrm{ES}}_{[\mathrm{Ru}]_{0}=2-10 \mathrm{mM}}$}} & \multicolumn{2}{|c|}{$\begin{array}{l}\mathrm{H}_{2}\left(P_{\mathrm{H} 2} \mathrm{MPa}\right) \\
\mathrm{RuPCY}(x \mathrm{~mol} \%) \\
\mathrm{NaBH}_{4}(10 x \mathrm{~mol} \%) \\
\mathrm{AL}-\mathrm{a}(2 x \mathrm{~mol} \%)\end{array}$} & \multirow{2}{*}{\multicolumn{2}{|c|}{$\underset{\text { ES-bb }}{\mathrm{Ph}\left(\mathrm{CH}_{2}\right)_{2} \mathrm{CO}_{2}\left(\mathrm{CH}_{2}\right)_{3} \mathrm{Pr}}$}} \\
\hline & & \multicolumn{2}{|c|}{$\mathrm{THF}, 160^{\circ} \mathrm{C}, t \mathrm{~h}$} & & \\
\hline entry & $\begin{array}{l}\text { RuPCY } \\
(x)\end{array}$ & $\begin{array}{l}P_{\mathrm{H} 2} \\
\text { (MPa) }\end{array}$ & $t(\mathrm{~h})$ & Al-b & ES-bb \\
\hline 1 & 1 & 1 & 8 & 77 & 7 \\
\hline 2 & 1 & 2 & 6 & 84 & 5 \\
\hline 3 & 1 & 4 & 4 & 89 & 2 \\
\hline 4 & 1 & 6 & 4 & 94 & 2 \\
\hline 5 & 0.4 & 6 & 24 & 72 & 8 \\
\hline 6 & 0.2 & 6 & 48 & 74 & \\
\hline 7 & 0.1 & 6 & 190 & 60 & 12 \\
\hline
\end{tabular}

Figure 8. Effect of $P_{\mathrm{H} 2}$ and amounts of RuPCY and catalytic AL-a on hydrogenation rate.

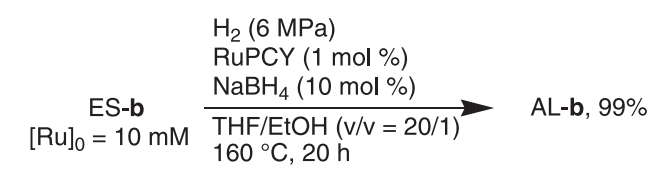

ably even under low $P_{\mathrm{H} 2}$ (entries 1-3 vs. 4). Catalyst loading was successfully reduced to the range of $0.1-0.4 \mathrm{~mol} \%$ (entries 5-7) and the maximum turnover number (TON) so far observed was ca. 720 (entry 7).

In an effort to elucidate how the alcohol affects catalyst preactivation, control experiments were carried out (Figure 9). When RuPCY was heated in toluene under $\mathrm{N}_{2}$ with $\mathrm{NaBH}_{4}$ in the absence or presence of EtOH (toluene/EtOH $(\mathrm{v} / \mathrm{v})=1 / 1)$, $\mathrm{RuPCY}-\mathrm{H}\left(\mathrm{BH}_{4}\right)$ was formed $(66 \%)$ only in the latter case. Therefore, the alcohol may activate $\mathrm{NaBH}_{4}$, promoting abstraction of chloro groups from a $\mathrm{Ru}$ center and liberating $\mathrm{NaCl}$, facilitating smooth generation of a $\mathrm{Ru}-\mathrm{H}$ species, even without $\mathrm{H}_{2}$. ${ }^{\mathrm{9r}, 29}$

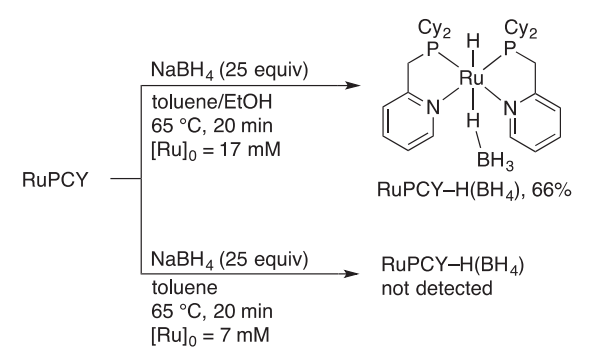

Figure 9. Effect of alcohol on formation of $\mathrm{Ru}$-hydride species (no $\mathrm{H}_{2}$ ).

The substrate generality of the ester hydrogenation system was tested using catalytic RuPCY, AL-a and $\mathrm{NaBH}_{4}$. The results are listed in eqs $11-16$. Methyl esters and $1^{\circ}$ alkoxy carbonyl compounds including bigger and smaller aliphatic esters (ES-c and - -g), aliphatic and aromatic diesters (ES-h and -i), and triesters (lipids (triglycerides) ES-j, $-\mathbf{k}$, and $-\mathbf{l}$ ) are all compatible with the present reaction conditions, giving $\mathrm{AL}-\mathbf{c}$ and $\mathrm{AL}-\mathbf{g}-\mathbf{l}$. The market demand of diol AL-i (eq. 14) is increasing very rapidly as a monomer of poly(urethane)s. ${ }^{30}$ Internal olefins were unfortunately hydrogenated (eq. 15). Three different lipids also underwent almost full conversion of all the interior ester moieties, albeit with the requirement of a higher $T$ and a prolonged $t$ (eq. 15). To the best of our knowledge, this is the first example of effective lipid hydrogenation using a homogeneous mononuclear $\mathrm{Ru}$ complex as a catalyst precursor. ${ }^{21}$ It is clear that in the hydrogenation of both amides and esters, RuPCY can essentially maintain a molecular structure of the form $\operatorname{Ru}(P, N)_{n}(n=1$ or 2$)$ even for a lengthy $t$ at high $T$. Thus, the catalyst generated during ester hydrogenation could be used subsequently for a different reaction.

$N$-benzyl-4-ethoxycarbonylpiperidine (ES-m), which has been proposed by Eisai Co., LTD. to be a cheaper alternative ingredient for production of donepezil, ${ }^{31}$ was also fully hydrogenated (eq. 16). This reaction encouraged us to seek out a set of different HT processes, in which dehydrogenation of (1benzylpiperidin-4-yl)methanol (AL-m) giving the aldehyde $N$-benzyl-4-formylpiperidine $(\mathrm{AH}-\mathbf{m})$, followed by aldol condensation (dehydration) of the aldehyde with ketone KE-a and subsequent chemoselective (transfer) hydrogenation of the olefin over the carbonyl group of the $\alpha, \beta$-unsaturated ketone $\mathrm{KE}-\mathbf{a m}$, gives donepezil (Figure 10). 


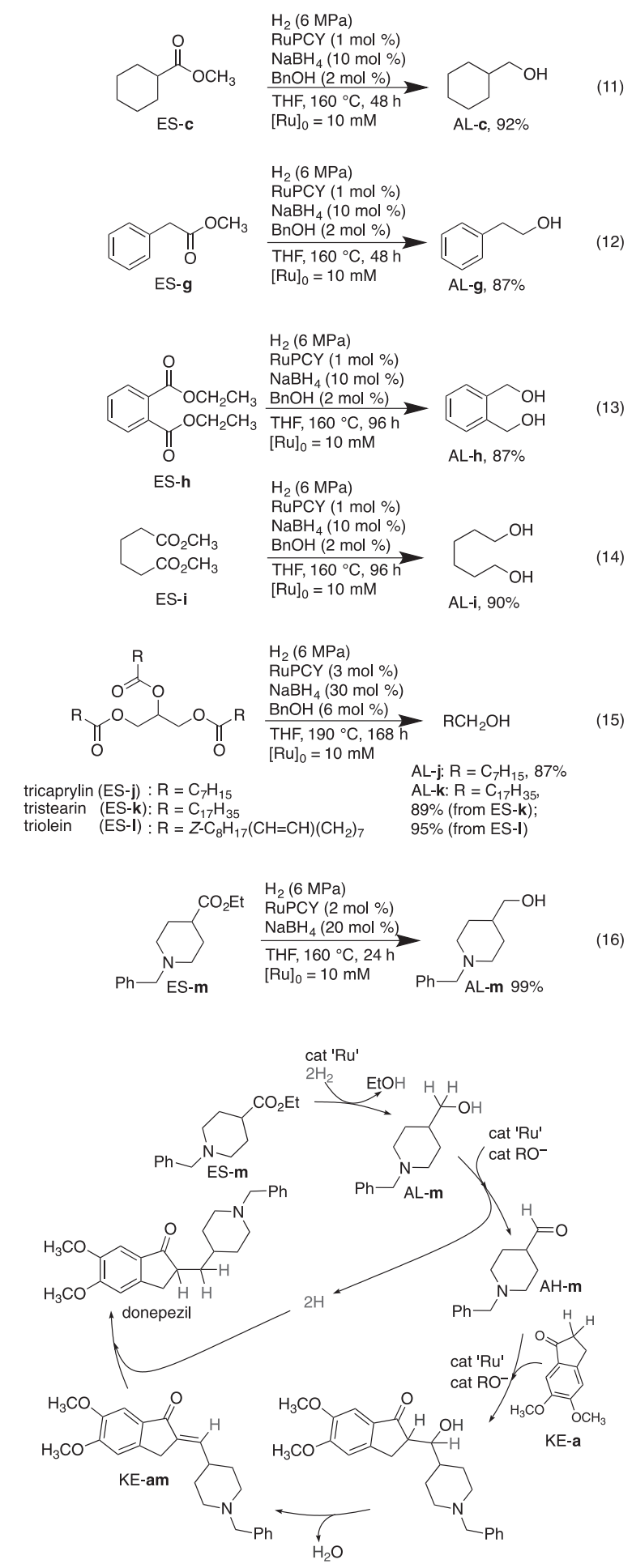

Figure 10. Proposed senario for intricate HyMA: multifaceted HT involving hydrogen movement from $2 \mathrm{H}_{2}$ to produce donepezil.

\section{Dehydrogenation of Alcohols for Carbon-Carbon Bond Formation}

\section{1 $\alpha$-Alkylation of Ketones Initiated by Dehydrogenation of $1^{\circ}$ and $2^{\circ}$ Alcohols and Subsequent (transfer) Hydrogena- tion: Donepezil Synthesis}

To complete the consecutive orthogonal HyMA processes for synthesis of donepezil, the capability of a single Ru complex (RuPCY), catalyzing different HT ((transfer) dehydroge-

nation/hydrogenation) reactions, was also surveyed in the alkylation of the $\alpha$-carbon of a ketone (KE) with an alcohol. Here, an $\alpha, \beta$-unsaturated ketone having two functional groups (an olefin and a carbonyl), both potentially susceptible to undergoing (transfer) hydrogenation, is the reaction intermediate. It is not a trivial task to control/limit the selectivity of hydrogen addition to an olefin vs. a carbonyl group using catalytic base and a transition metal catalyst in cross-coupling reactions involving HT. 5,6-dimethoxy-1-indanone (KE-a) was chosen as a model substrate, since $\mathrm{KE}-\mathbf{a}$ serves as a pivotal carbon fragment of donepezil. $\mathrm{KE}-\mathbf{a}$ was reacted with various alcohols including $\mathrm{CH}_{3} \mathrm{OH}, 1^{\circ}$ and $2^{\circ}$ alcohols (Figure 11) in the presence of RuPCY (1 mol \%).

$\mathrm{RuPCY}(1 \mathrm{~mol} \%)$
$\begin{aligned} & \mathrm{NaOtBu}(10 \mathrm{~mol} \%) \\ & \text { toluene, } 160^{\circ} \mathrm{C}, 24 \mathrm{~h} \\ & {[\mathrm{Ru}]_{0}=10 \mathrm{mM}}\end{aligned}$

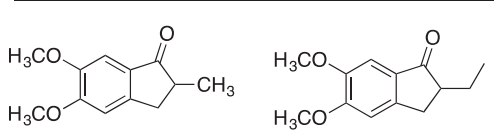

KE-b, $17 \%(14 \%)$

KE-c, $72 \%$

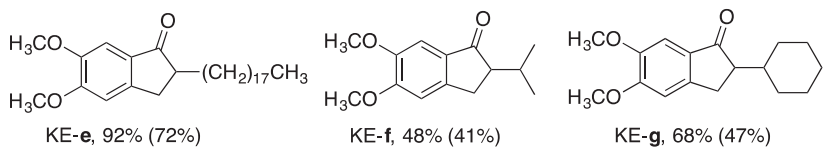

Figure 11. $\alpha$-Alkylation of $\mathrm{KE}-\mathbf{a} . \mathrm{R}=\mathrm{CH}_{3}(400 \mathrm{~mol} \%), \mathrm{Et}$ $(170 \mathrm{~mol} \%), \mathrm{PhCH}_{2}, \mathrm{CH}_{3}\left(\mathrm{CH}_{2}\right)_{17}, i \operatorname{Pr}(400 \mathrm{~mol} \%)$, and $\mathrm{Cy}$. Values in parentheses are isolated yields.

Without purging $\mathrm{H}_{2}$, the $\alpha$-alkylation proceeded under $\mathrm{N}_{2}$ most selectively with high productivity using $\mathrm{NaO} t \mathrm{Bu}$ $(10 \mathrm{~mol} \%)$ as the base additive, where the ketone functionality consistently remained unreacted. Using $\mathrm{NaO} t \mathrm{Bu}$ or $\mathrm{KO} t \mathrm{Bu}$ alone, no reaction took place. Less volatile $1^{\circ}$ alcohols such as $\mathrm{AL}-\mathbf{a}$ were generally among the most efficient substrates for such selective $\alpha$-alkylation (KE-a:ROH (mol:mol)=1:1), while the more volatile $\mathrm{MeOH}$ and $\mathrm{EtOH}$, and $2^{\circ}$ alcohols including $i \mathrm{PrOH}$ and $\mathrm{CyOH}$, were used in excess amounts, affording $\alpha^{-}$ alkylation in low to good yields. The HT-based $\alpha$-alkylation of a ketone with a $2^{\circ}$ alcohol, which corresponds to a direct crossed aldol condensation of two different ketones giving $\beta, \beta$-disubstituted- $\alpha, \beta$-unsaturated ketones, followed by selective (transfer) hydrogenation of the resulting interior olefin, appears only very scarcely in the literature. ${ }^{6,16 \mathrm{j}, \mathrm{k}}$

A similar catalyst system was applied to the $\alpha$-alkylation of $\mathrm{KE}-\mathbf{a}$ with $\mathrm{AL}-\mathbf{m}$ for the synthesis of donepezil. Screening of additives and solvents using precatalyst RuPCY was carried out in the absence of $\mathrm{H}_{2}$ gas. Donepezil was not obtained at all without RuPCY. Under the reaction conditions, toluene was the solvent of choice, rather than THF or dioxane. A combination of $\mathrm{NaBH}_{4}(10 \mathrm{~mol} \%)$ and RuPCY $(1 \mathrm{~mol} \%)$ in THF (the conditions which were the most effective for ester hydrogenation) was less satisfactory for the $\alpha$-alkylation of $\mathrm{KE}-\mathbf{a}$ (donepezil: $37 \%$ with $T=160{ }^{\circ} \mathrm{C}, t=24 \mathrm{~h}$ ). Different additives had a significant influence on the reaction rate, and donepezil (99\%) was obtained most effectively again with catalytic $\mathrm{NaO} t \mathrm{Bu}$ (eq. 17). A shortened reaction $(t=1 \mathrm{~h})$ even afforded $72 \%$ of donepezil under otherwise identical conditions.

Although $\mathrm{AH}-\mathbf{m}$ has been thought to be a key intermedi- 


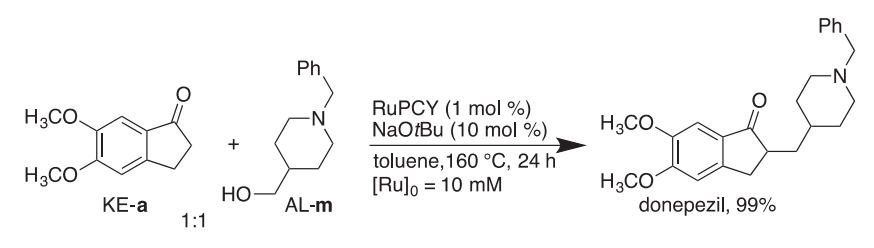

ate ${ }^{31}$ this result is in contrast to the prior synthesis and isolation of $\mathrm{AH}-\mathbf{m}$ (Figure 12), in which formation of salt waste could not be avoided. ${ }^{32}$

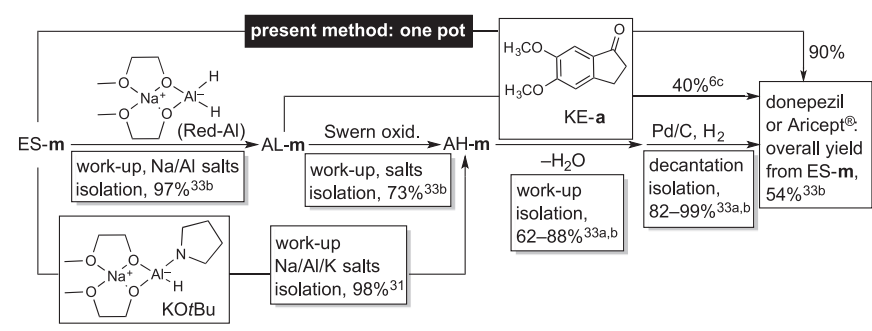

Figure 12. Conventional synthesis of donepezil in three-to-four batch reactions, compared with present method.

\section{2 $\alpha$-Alkylation of Ketones Initiated by Hydrogenation of Esters Followed by Dehydrogenation of $1^{\circ}$ Alcohols: Donepezil Synthesis}

Although it was considerably challenging, synthesis of donepezil from ES-m using multistep HyMA catalysis was carried out in a one-pot operation using the same RuPCY precatalyst (Figure 13). The optimal additives and solvents were different for hydrogenation of ES-m and $\alpha$-alkylation of $\mathrm{KE}-\mathbf{a}$ with $\mathrm{AL}-\mathbf{m}$. The hydrogenation of $\mathrm{ES}-\mathbf{m}$ in THF was followed by addition of $\mathrm{KE}-\mathbf{a}, \mathrm{NaO} t \mathrm{Bu}$ and excess toluene. The reaction mixture $(\mathrm{THF} /$ toluene $(\mathrm{v} / \mathrm{v})=1 / 1)$ was subjected to the reaction conditions for the subsequent $\alpha$-alkylation step (Figure 13a). By carrying out the $\alpha$-alkylation of the crude mixture of $\mathrm{KE}-\mathbf{a}$ at $160{ }^{\circ} \mathrm{C}$ without removal of any volatile components produced in the first (hydrogenation) step, donepezil was obtained in 49\% yield; however, 2-ethyl-5,6-dimethoxy-1-indanone (KE-c, Figure 11) was also obtained in $36 \%$ yield. The EtOH generated during the hydrogenation of ES-m in the first step reacted smoothly with $\mathrm{KE}-\mathbf{a}$ giving $\mathrm{KE}-$ c.

In order to remove the EtOH generated in the ester hydro-

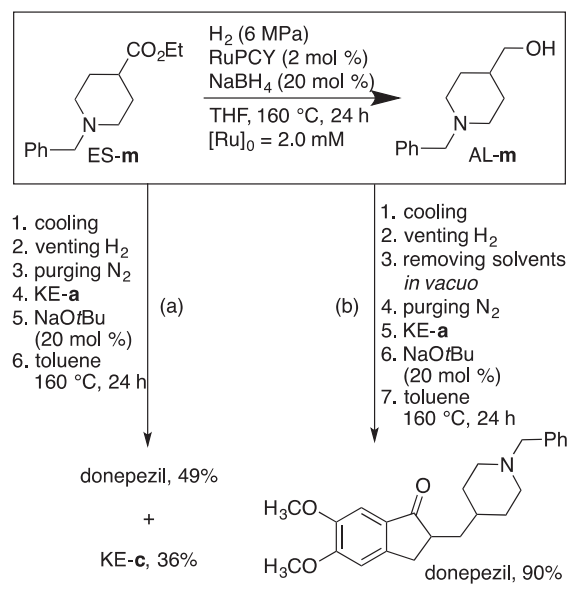

Figure 13. Synthesis of donepezil in one pot through multifaceted HyMA. genation step before proceeding to the $\alpha$-alkylation step, the solvent was evaporated in vacuo after the hydrogenation of ES-m, and toluene was added to the residual mixture for the second step. As a representative procedure (Figure 13b), a THF solution of ES $-\mathbf{m}$ was hydrogenated $\left(P_{\mathrm{H} 2}=6 \mathrm{MPa}\right)$ using RuPCY $(2 \mathrm{~mol} \%)$ and $\mathrm{NaBH}_{4}(20 \mathrm{~mol} \%)$ at $160{ }^{\circ} \mathrm{C}$ for $24 \mathrm{~h}$. After the autoclave cooled, $\mathrm{H}_{2}$ gas was carefully vented from the leak valve and the solvent was removed in vacuo at $100{ }^{\circ} \mathrm{C}$ for $1 \mathrm{~h}$. Finally, $\mathrm{KE}-\mathbf{a}, \mathrm{NaO} t \mathrm{Bu}(20 \mathrm{~mol} \%)$ and toluene were added to the crude mixture in a Teflon tube inserted into the autoclave, and the reaction was resumed under $\mathrm{N}_{2}\left(T=160{ }^{\circ} \mathrm{C}\right.$, $t=5 \mathrm{~h}$ ). Donepezil was obtained in $\sim 90 \%$ yield (by NMR). In the reported synthesis (Figure 12), ${ }^{31,33}$ donepezil was available from ES-m in four steps ${ }^{33 b}$ using four reaction vessels and giving non-negligible amounts of different salt wastes. On the other hand, we succeeded in synthesizing donepezil from ES$\mathbf{m}$ via multistep HT processes in a one-pot operation. Furthermore, the amount and variety of salt wastes generated during the reactions were significantly reduced in comparison with any prior donepezil synthetic approaches. ${ }^{33}$ Thus, it has been demonstrated here that a HyMA strategy can serve as an overwhelmingly powerful concept for achieving high atom- and step economy when combining various processes in a single reaction vessel.

4.3 $\alpha$-Alkylation of Ketones for Pyrrole Synthesis Initiated by Dehydrogenation of $\beta$-Amino $1^{\circ}$ Alcohols: Rapid

Access to the Core Pyrrole Structure of Lipitor ${ }^{\circledR}$

As demonstrated in the donepezil synthesis (eq. 17 and Figure 13), a HyMA process starting from (transfer) dehydrogenation of an alcohol followed by a crossed aldol reaction can be a useful tool in organic synthesis. In order to expand the potential of RuPCY as catalyst in the $\alpha$-alkylation of ketone(s), simple alcohols used (Figure 11) were switched to more functionalized alcohols such as $\beta$-amino alcohols.

Related fundamental processes, frequently referred to as "hydrogen autotransfer," lk,l "borrowing hydrogen," li or "acceptorless dehydrogenation," have usually been carried out using a transition-metal catalyst based on $\mathrm{Ru},{ }^{34} \mathrm{Ir},{ }^{16,34} \mathrm{Ni},{ }^{35} \mathrm{Pd},{ }^{16,36}$ $\mathrm{Ag},{ }^{37} \mathrm{Cu},{ }^{16 h, 1,38} \mathrm{Fe}^{39}$ or $\mathrm{Au}^{40}$ in the presence of a stoichiometric (or in rare cases, catalytic ${ }^{161}$ ) amount of an alkali metal base. Non-transition metal-based systems, ${ }^{6 a}$ e.g., stoichiometric $\mathrm{KO} t \mathrm{Bu}^{-},{ }^{42}$ and catalytic $\mathrm{KOH}$ (or $\mathrm{NaOH}$ )/air- ${ }^{41}$ or $\mathrm{NaOH} / \mathrm{H}_{2}-$ promoted versions, ${ }^{43 \mathrm{a}}$ can also be effective. However, detailed studies are lacking as to which species, the transition metal or the base, is more responsible for the catalysis. Our original studies demonstrated that even "only base" could promote the $\alpha-$ akylation of ketones ${ }^{161}$ or $\beta$-alkylation of alcohols with alcohols, ${ }^{43 a}$ but RuPCY could cooperate significantly with the base in promoting the catalysis. Thus, a virtually salt-free and highly versatile synthesis of $N$-unsubstituted pyrroles (PY) using a catalytic amount of RuPCY and an alkali metal base, in which readily available and easily varied ketones (KE) react with $\alpha$-amino aldehydes generated in situ from fully unmasked $\beta$-amino alcohols, was attempted (Figure 14).

From a synthetic point of view, successful control of the reactivity of otherwise unstable "fully unmasked" $\alpha$-amino aldehydes in cross-coupling reaction is rare. Fully unmasked $\alpha$-amino aldehydes are notoriously unstable synthetic intermediates, difficult to isolate, and rarely used in organic synthesis. ${ }^{44}$ For example, rapid degradation of valinal is accompanied by self-dimerization giving the symmetric pyrazine. ${ }^{45}$ Recently, 


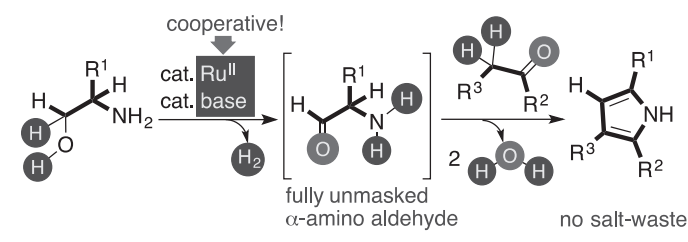

Figure 14. Overview of dehydrogenative and dehydrative HyMA involved in the synthesis of pyrrole rings.

Ishii, ${ }^{46} \mathrm{Kempf}^{47}{ }^{4}$ Milstein ${ }^{48}$ and Beller ${ }^{22 \mathrm{~b}, 49}$ reported a similar pyrrole synthesis starting from $\beta$-amino alcohols (or its equivalent, a combination of $1^{\circ}$ amines and ethylene glycol derivatives). That system was further extended to the syntheses of pyridine and quinoline derivatives using $\gamma$-amino alcohols in place of $\beta$-amino alcohols. ${ }^{50}$ Nevertheless, it had proved possible for us to couple two different unmasked $\beta$-amino alcohols giving substituted pyrroles using rhodium catalysts with catalytic alkali metal base ${ }^{43 b}$ and to couple ketones and $\beta-$ amino alcohols using only a catalytic amount of $\mathrm{NaOH}$ or $\mathrm{KO}$ t $\mathrm{Bu}$ without any transition metals. ${ }^{43 \mathrm{a}}$

To begin, a 1:2 molar ratio of valinol (AA-a) to propiophenone $(\mathrm{KE}-\mathbf{h})$ was subjected to catalytic amounts of RuPCY and $\mathrm{KO} t \mathrm{Bu}$ in toluene to synthesize 2,3,5-trisubstituted pyrrole PY-ah (eq. 18).

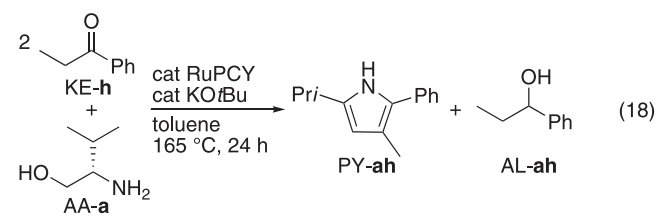

We knew from our previous studies ${ }^{43}$ that the concentration of alkali metal alkoxide significantly affects catalytic activity, depending on the solvent used, presumably due to the structure diversity of different clusters of alkoxides and enolates (dimers, tetramers, hexamers, etc.) which also show intricate structural dynamics. ${ }^{51}$ Therefore, the effect of several factors, namely $[\mathrm{RuPCY}]_{0},(0-15 \mathrm{mM} ; 0-2 \mathrm{~mol} \%$ relative to AAa), $[\mathrm{KO} t \mathrm{Bu}]_{0}(25-74 \mathrm{mM} ; 10 \mathrm{~mol} \%)$, and $[\mathrm{KO} t \mathrm{Bu}]_{0} /[\mathrm{RuPCY}]_{0}$ (1/0 to $100 / 1)$, on the yield of PY-ah were investigated. The noteworthy results obtained during the investigation of the synthesis of 2,3,5-trisubstituted pyrroles are: (1) without RuPCY, the yield of pyrrole PY-ah averaged around 30\% using catalytic $\mathrm{KO} t \mathrm{Bu}$. In order to obtain $\mathrm{PY}-\mathbf{a h}$ in higher yields in the presence of RuPCY (than in its absence), $[\mathrm{KO} t \mathrm{Bu}]_{0}$ should be higher than $37 \mathrm{mM}$; (2) In contrast, when $[\mathrm{KO} t \mathrm{Bu}]_{0}$ was lower (e.g., $25 \mathrm{mM}$ ), the best yield of PY-ah ( 40\%) was obtained without RuPCY $(0.25-2 \mathrm{~mol} \%)$. In this case, the addition of RuPCY was detrimental to the effective production of PY-ah; (3) at a higher concentration of $[\mathrm{KO} t \mathrm{Bu}]_{0}$ $(74 \mathrm{mM})$, a $[\mathrm{KO} t \mathrm{Bu}]_{0} /[\mathrm{RuPCY}]_{0}$ of $40\left([\mathrm{RuPCY}]_{0}=1.9 \mathrm{mM}\right)$ gave the highest yield of $\mathrm{PY}-\mathbf{a h}(52 \%)$ with $\mathrm{AA}-\mathbf{a} / \mathrm{KE}-\mathbf{h}=$ $\sim 1.2$; (4) The $[\mathrm{KO} t \mathrm{Bu}]_{0} /[\mathrm{RuPCY}]_{0}$ ratio was more critical than the $[\mathrm{AA}-\mathbf{a}]_{0}$ or $[\mathrm{KE}-\mathbf{h}]_{0}$ to the reaction rate in the dehydrogenation of $\mathrm{AA}^{-\mathbf{a}}$ (which corresponds to the yield of $\mathrm{AL}-\mathbf{a h}$ ), and to an increase in the apparent overall reaction rate leading to PY-ah. All these preliminary experiments suggest that RuPCY would help the role of $(\mathrm{KO} t \mathrm{Bu})_{n}$ clusters or vice versa, although it is difficult to ascertain which chemical entity is the major player for inducing catalysis.
Among the higher concentrations of $[\mathrm{KO} t \mathrm{Bu}]_{0}$ tested, nonsolvent (neat) conditions $\left([\mathrm{KO} t \mathrm{Bu}]_{0}=\mathrm{ca} .260 \mathrm{mM} ;[\mathrm{RuPCY}]_{0}\right.$ $=6-7 \mathrm{mM})$ afforded the highest yield of PY-ah $(77 \%)$. When other ruthenium complexes, such as $\mathrm{CpRuCl}\left(\mathrm{PPh}_{3}\right)_{2}$ $(0.25 \mathrm{~mol} \%)$ and $\left[(p-\text { cymene }) \mathrm{RuCl}_{2}\right]_{2} \quad(0.125 \mathrm{~mol} \%)$, were reacted for $6 \mathrm{~h}$ in place of RuPCY under otherwise identical neat conditions, $\mathrm{PY}-$ ah was obtained in lower yields ( $49 \%$ and $32 \%$, respectively). Not more than one out of two equiv of $\mathrm{KE}-\mathbf{h}$ relative to AA-a should be required to work as the $\mathrm{H}_{2}$ acceptor for the synthesis of 2,3,5-trisubstituted pyrroles. Examples of catalytic synthesis of 2,3,5-trisubstituted pyrroles PY-ah-ak, PY-bh, PY-bk, PY-ch, and PY-dh using RuPCY $(0.25 \mathrm{~mol} \%)$ under neat conditions using $\beta$-amino alcohols $\mathrm{AA}-\mathbf{a}-\mathbf{d}$ and ketones KE-h-k are summarized (Figure 15). $\mathrm{KE}-\mathbf{h}-\mathbf{k}$ also worked as hydrogen acceptors and ALs are always generated as sacrificial byproducts.

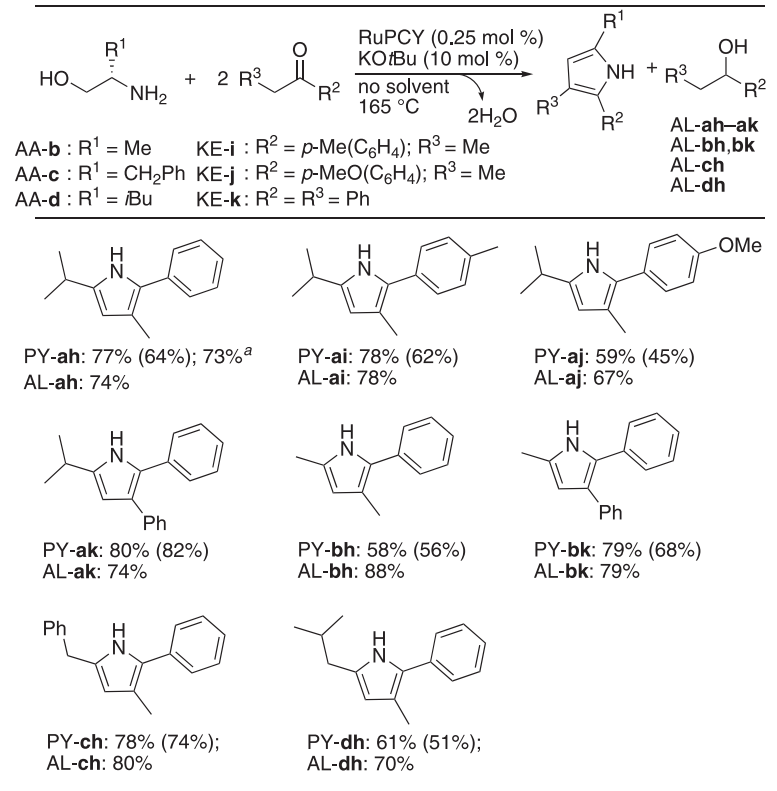

Figure 15. Unless otherwise specified, the solvent-free reaction was carried out at $165^{\circ} \mathrm{C}$ for $24 \mathrm{~h}$ under $\mathrm{N}_{2}$ with $[\mathrm{KO} t \mathrm{Bu}]_{0}=\mathrm{ca}$. $260 \mathrm{mM} ; \quad[\mathrm{KO} t \mathrm{Bu}]_{0} /[\mathrm{Ru}]_{0}=40 ; \quad \mathrm{RuPCY}: \mathrm{KO} t \mathrm{Bu}: \mathrm{AA}: \mathrm{KE}=$ 1:40:400:800. Yields $\%$ are based on AA, determined by ${ }^{1} \mathrm{H}$ NMR. The values in parentheses are of isolated, purified PY. ${ }^{a} t=6 \mathrm{~h}$.

In contrast, the reaction of $\mathrm{AA}-\mathbf{a}$ with methyl ketones such as acetophenone (KE-l) that gives 2,5-disubstituted pyrrole (e.g., PY-al) was unselective under such solvent-free, "neat" conditions. Rather, a more dilute toluene solution, with $[\mathrm{KO} t \mathrm{Bu}]_{0}=\mathrm{ca} .90 \mathrm{mM}$ and $[\mathrm{RuPCY}]_{0}=2-3 \mathrm{mM}(1 \mathrm{~mol} \%)$, was promising for the prevention of the self-dimerization of KE-l. The reactions were faster and nearly complete within $3 \mathrm{~h}$. Evolution of $\mathrm{H}_{2}$ was detected in all cases by micro-GC analysis, demonstrating the acceptorless dehydrogenation ${ }^{1 f}$ followed by a bimolecular aldol reaction. Synthesis of 2,5-disubstituted pyrroles PY-al-an, PY-cl and PY-ao using amino alcohols and different ketones KE-l-o are listed (Figure 16).

The versatile nature of this approach was further demonstrated by the shortest access to the core pyrrole (PY-ap) of Lipitor $^{\circledR}$ (atorvastatin calcium) ${ }^{52}$ upon reaction of the natural resource AA-a with $\mathrm{KE}-\mathbf{p}$ (eq. 19). 2,3,4,5-Tetraphenyl-1 $H_{-}$ pyrrole $^{53}$ (PY-ek) was formed by reaction of AA-e with KE-k in a simplest way (eq. 20). In these cases, PY-ap and PY-ek 


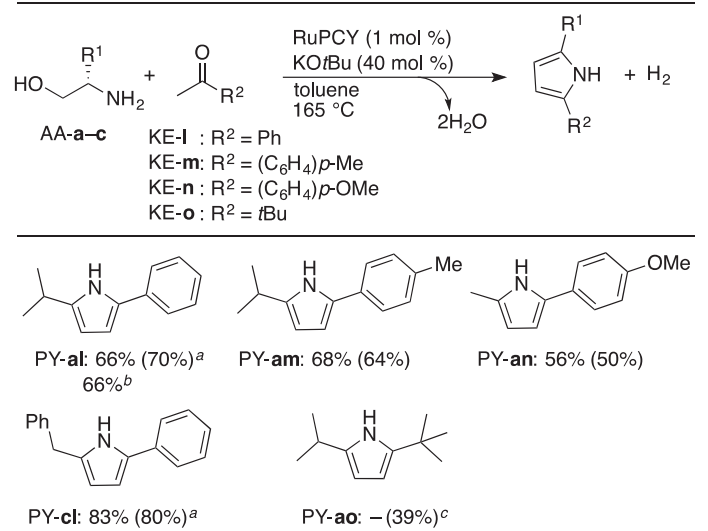

Figure 16. Unless otherwise specified, the reaction was carried out in toluene for $3 \mathrm{~h}$ under $\mathrm{N}_{2}$ with $[\mathrm{KO} t \mathrm{Bu}]_{0}=\mathrm{ca} .90 \mathrm{mM}$; $[\mathrm{KO} t \mathrm{Bu}]_{0} /[\mathrm{Ru}]_{0}=40 ; \mathrm{RuPCY}: \mathrm{KO} t \mathrm{Bu}: \mathrm{AA}: \mathrm{KE}=1: 40: 150: 100$. Yields are based on KE, determined by ${ }^{1} \mathrm{H}$ NMR. The values in parentheses are of isolated, purified PY. ${ }^{a} t=24 \mathrm{~h}$. ${ }^{b} \mathrm{AA}-\mathbf{a}: \mathrm{KE}-\mathbf{l}=1: 1$. ${ }^{c}$ Reaction conditions, those described in the footnote in Figure 15.

were not formed without using RuPCY, as ascertained by ${ }^{1} \mathrm{H}$ NMR. PY-ap was synthesized previously in a more tedious multistep reaction ${ }^{54}$ or via three component coupling ${ }^{22 b, 49}$ prior to being converted to Lipitor ${ }^{\circledR}$ through a few synthetic steps. ${ }^{54}$
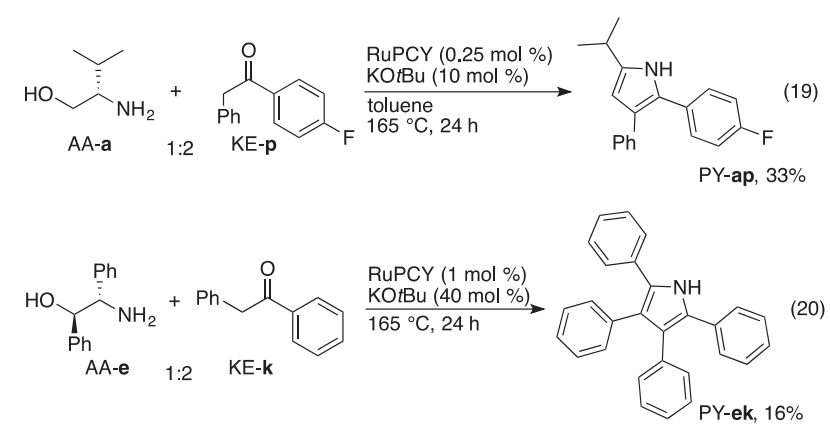

\section{Conclusion}

A HyMA strategy based on the use of RuPCY has been shown to be effective for controlling diverse HTs, thereby rendering multiple, separate processes consecutive for the rapid synthesis of valuable products, e.g., donepezil and Lipitor ${ }^{\circledR}$. The results constitute a paradigm shift from a synthesis generating salt (metallic) waste to a HyMA-based atom- and stepeconomical synthesis. The multistep synthesis starting from inert organic substances in high oxidation states is consisted of a new portfolio of selective reduction (functional group transformation) and subsequent skeletal carbon-carbon bondforming reactions using alcohol.

\section{References}

1) (a) Chelucci, G.; Baldino, S.; Baratta, W. Acc. Chem. Res. 2015, 48, 363. (b) Werkmeister, S.; Neumann, J.; Junge, K.; Beller, M. Chem. Eur. J. 2015, 21, 12226. (c) Pritchard, J.; Filonenko, G. A.; Van Putten, R.; Hensen, E. J. M.; Pidko, E. A. Chem. Soc. Rev. 2015, 44, 3808. (d) Werkmeister, S.; Junge, K.; Beller, M. Org. Process Res. Dev. 2014, 18 , 289. (e) Balaraman, E.; Milstein, D. Top. Organomet. Chem. 2014, 48, 19. (f) Gunanathan, C.; Milstein, D. Science 2013, 341, 1229712. (g) Clarke, M. L. Catal. Sci. Technol. 2012, 2, 2418. (h) Dobereiner, G. E.; Crabtree, R. H. Chem. Rev. 2010, 110, 681. (i) Nixon, T. D.; Whittlesey, M. K.; Williams, J. M. J. Dalton Trans. 2009, 753. (j)
Hamid, M. H. S. A.; Slatford, P. A.; Williams, J. M. J. Adv. Synth. Catal. 2007, 349, 1555. (k) Guillena, G.; Ramón, D. J.; Yus, M. Angew. Chem. Int. Ed. 2007, 46, 2358. (1) Obora, Y. Top. Curr. Chem. 2016 $374,11$.

2) (a) Dutta, I.; Sarbajna, A.; Pandey, P.; Rahaman, S. M. W.; Singh, K.; Bera, J. K. Organometallics 2016, 35, 1505. (b) Bonitatibus, P. J.; Chakraborty, S.; Doherty, M. D.; Siclovan, O.; Jones, W. D.; Soloveichik, G. L. Proc. Natl. Acad. Sci. 2015, 112, 1687. (c) Chakraborty, S.; Lagaditis, P. O.; Förster, M.; Bielinski, E. A.; Hazari, N.; Holthausen, M. C.; Jones, W. D.; Schneider, S. ACS Catal. 2014, 4 3994. (d) Trincado, M.; Banerjee, D.; Grützmacher, H. Energy Environ. Sci. 2014, 7, 2464. (e) Yang, X. ACS Catal. 2013, 3, 2684. (f) Kawahara, R.; Fujita, K.; Yamaguchi, R. J. Am. Chem. Soc. 2012, 134, 3643. (g) Nielsen, M.; Kammer, A.; Cozzula, D.; Junge, H.; Gladiali, S.; Beller, M. Angew. Chem. Int. Ed. 2011, 50, 9593. (h) Bertoli, M.; Choualeb, A.; Lough, A. J.; Moore, B.; Spasyuk, D.; Gusev, D. G. Organometallics 2011, 30, 3479. (i) Johnson, T. C.; Morris, D. J.; Wills, M. Chem. Soc. Rev. 2010, 39, 81.

3) (a) Xie, J.-H.; Bao, D.-H.; Zhou, Q.-L. Synthesis 2015, 47, 460. (b) Li, Y.-Y; Yu, S.-L; Shen, W.-Y; Gao, J-X. Acc. Chem. Res. 2015 48, 2587. (c) Ohkuma, T. Proc. Japan Acad. Ser. B 2010, 86, 202. (d) Noyori, R.; Ohkuma, T. Angew. Chem. Int. Ed. 2001, 40, 40

4) (a) Chakraborty, S.; Piszel, P. E.; Brennessel, W. W.; Jones, W. D. Organometallics 2015, 34, 5203. (b) Chakraborty, S.; Piszel, P. E.; Brennessel, W. W.; Jones, W. D. Organometallics 2015, 34, 5203. (c) Tseng, K.-N. T.; Kampf, J. W.; Szymczak, N. K. ACS Catal. 2015, 5 , 5468. (d) Zeng, G.; Sakaki, S.; Fujita, K. I.; Sano, H.; Yamaguchi, R. ACS Catal. 2014, 4, 1010. (e) Kawahara, R.; Fujita, K. I.; Yamaguchi, R. Angew. Chem. Int. Ed. 2012, 51, 12790.

5) (a) Li, H.; Mazet, C. Acc. Chem. Res. 2016, 49, 1232. (b) Cahard, D.; Gaillard, S.; Renaud, J. L. Tetrahedron Lett. 2015, 56, 6159. (c) Larionov, E.; Lin, L.; Guénée, L.; Mazet, C. J. Am. Chem. Soc. 2014 136, 16882. (d) Mantilli, L.; Gérard, D.; Torche, S.; Besnard, C.; Mazet, C. Angew. Chem. Int. Ed. 2009, 48, 5143. (e) Ito, M.; Kitahara, S.; Ikariya, T. J. Am. Chem. Soc. 2005, 127, 6172. (f) Uma, R.; Crévisy, C.; Grée, R. Chem. Rev. 2003, 103, 27.

6) Reviews: (a) Huang, F.; Liu, Z.; Yu, Z. Angew. Chem. Int. Ed. 2016 55, 862. (b) Cini, E.; Petricci, E.; Truglio, G. I.; Vecchio, M.; Taddei, M. $R S C A d v$. 2016, 6, 31386. Recent reports: (c) Schlepphorst, C. Maji, B.; Glorius, F. ACS Catal. 2016, 6, 4184. (d) Lundberg, H.; Adolfsson, H. Synthesis 2016, 48, 644. (e) Quan, X.; Kerdphon, S.; Andersson, P. G. Chem. Eur. J. 2015, 21, 3576. (f) Frost, J. R.; Cheong, C. B.; Akhtar, W. M.; Caputo, D. F. J.; Stevenson, N. G.; Donohoe, T. J. J. Am. Chem. Soc. 2015, 137, 15664. (g) Dang, T. T. Shan, S. P.; Ramalingam, B.; Seayad, A. M. RSC Adv. 2015, 5, 42399. (h) Ogawa, S.; Obora, Y. Chem. Commun. 2014, 50, 2491. (i) Wang, D.; Zhao, K.; Ma, P.; Xu, C.; Ding, Y. Tetrahedron Lett. 2014, 55 , 7233. (j) Yamada, Y. M. A.; Uozumi, Y. Tetrahedron 2007, 63, 8492. (k) Fujita, K.; Asai, C.; Yamaguchi, T.; Hanasaka, F.; Yamaguchi, R. Org. Lett. 2005, 7, 4017. (1) Yamada, Y. M. A.; Uozumi, Y. Org. Lett. 2006, $8,1375$.

7) (a) Guo, L.; Ma, X.; Fang, H.; Jia, X.; Huang, Z. Angew. Chem. Int. Ed. 2015, 54, 4023. (b) Iuchi, Y.; Obora, Y.; Ishii, Y. J. Am. Chem. Soc. 2010, 132, 2536 .

8) (a) Yao, W.; Ma, X.; Guo, L.; Jia, X.; Hu, A.; Huang, Z. Tetrahedron Lett. 2016, 57, 2919. (b) Guo, L.; Liu, Y.; Yao, W.; Leng, X.; Huang, Z. Org. Lett. 2013, 15, 1144.

9) (a) Elangovan, S.; Wendt, B.; Topf, C.; Bachmann, S.; Scalone, M.; Spannenberg, A.; Jiao, H.; Baumann, W.; Junge, K.; Beller, M. Adv. Synth. Catal. 2016, 358, 820. (b) Kim, D.; Le, L.; Drance, M. J.; Jensen, K. H.; Bogdanovski, K.; Cervarich, T. N.; Barnard, M. G; Pudalov, N. J.; Knapp, S. M. M.; Chianese, A. R. Organometallics 2016, 35, 982. (c) Tan, X.; Wang, Y.; Liu, Y.; Wang, F.; Shi, L.; Lee, K. H.; Lin, Z.; Lv, H.; Zhang, X. Org. Lett. 2015, 17, 454. (d) Filonenko, G. A.; Aguila, M. J. B.; Schulpen, E. N.; van Putten, R.; Wiecko, J.; Müller, C.; Lefort, L.; Hensen, E. J. M.; Pidko, E. A. J. Am. Chem. Soc. 2015, 137, 7620. (e) Spasyuk, D.; Vicent, C.; Gusev, D. G. J. Am Chem. Soc. 2015, 137, 3743. (f) Tan, X.; Wang, Q.; Liu, Y.; Wang, F.; Lv, H.; Zhang, X. Chem. Commun. 2015, 51, 12193. (g) Fairweather N. T.; Gibson, M. S.; Guan, H. Organometallics 2015, 34, 335. (h) Srimani, D.; Mukherjee, A.; Goldberg, A. F. G.; Leitus, G.; DiskinPosner, Y.; Shimon, L. J. W.; Ben David, Y.; Milstein, D. Angew. Chem. Int. Ed. 2015, 54, 12357. (i) Li, W.; Xie, J.; Yuan, M.; Zhou, Q. Green Chem. 2014, 16, 4081. (j) Miyada, T.; Huang Kwan, E.; Yamashita, M. Organometallics 2014, 33, 6760. (k) Spasyuk, D. Smith, S.; Gusev, D. G. Angew. Chem. Int. Ed. 2013, 52, 2538. (1) Fogler, E.; Iron, M. A.; Zhang, J.; Ben-David, Y.; Diskin-Posner, Y.; 
Leitus, G.; Shimon, L. J. W.; Milstein, D. Inorg. Chem. 2013, 52, 11469. (m) Acosta-Ramirez, A.; Bertoli, M.; Gusev, D. G.; Schlaf, M. Green Chem. 2012, 14, 1178. (n) Kuriyama, W.; Matsumoto, T.; Ogata, O.; Ino, Y.; Aoki, K.; Tanaka, S.; Kobayashi, T.; Sayo, N.; Saito, T. Org. Process Res. Dev. 2012, 16, 166. (o) Spasyuk, D.; Gusev, D. G. Organometallics 2012, 31, 5239. (p) Spasyuk, D.; Smith, S.; Gusev, D. G. Angew. Chem. Int. Ed. 2012, 51, 2772. (q) Ito, M.; Ootsuka, T.; Watari, R.; Shiibashi, A.; Himizu, A.; Ikariya, T. J. Am. Chem. Soc. 2011, 133, 4240. (r) Kuriyama, W.; Ino, Y.; Ogata, O.; Sayo, N.; Saito, T. Adv. Synth. Catal. 2010, 352, 92. (s) Takebayashi, S.; Bergens, S. H. Organometallics 2009, 28, 2349. (t) Saudan, L.; Saudan, C. M.; Debieux, C.; Wyss, P. Angew. Chem. Int. Ed. 2007, 46, 7473. (u) Zhang, J.; Leitus, G.; Ben-David, Y.; Milstein, D. Angew. Chem. Int. Ed. 2006, 45, 1113 .

10) (a) Naruto, M.; Saito, S. Nat. Commun. 2015, 6, 8140. (b) Korstanje, T. J.; Ivar van der Vlugt, J.; Elsevier, C. J.; de Bruin, B. Science 2015, 350, 298. (c) Cui, X.; Li, Y.; Topf, C.; Junge, K.; Beller, M. Angew. Chem. Int. Ed. 2015, 54, 10596. (d) V. Stein, T.; Meuresch, M.; Limper, D.; Schmitz, M.; Hölscher, M.; Coetzee, J.; Cole-Hamilton, D. J.; Klankermayer, J.; Leitner, W. J. Am. Chem. Soc. 2014, 136, 13217. (e) Brewster, T. P.; Miller, A. J. M.; Heinekey, D. M.; Goldberg, K. I. J. Am. Chem. Soc. 2013, 135, 16022. (f) Geilen, F. M. A.; Engendahl, B.; Harwardt, A.; Marquardt, W.; Klankermayer, J.; Leitner, W. Angew. Chem. Int. Ed. 2010, 49, 5510. (g) Bianchi, M.; Menchi, G.; Francalanci, F.; Piacenti, F.; Matteoli, U.; Frediani, P.; Botteghi, C. J. Organomet. Chem. 1980, 188, 109.

11) (a) Garg, J. A.; Chakraborty, S.; Ben-David, Y.; Milstein, D. Chem. Commun. 2016, 52, 5285. (b) Schneck, F.; Assmann, M.; Balmer, M.; Harms, K.; Langer, R. Organometallics 2016, 35, 1931. (c) Meuresch, M.; Westhues, S.; Leitner, W.; Klankermayer, J. Angew. Chem. Int. Ed. 2016, 55, 1392. (d) Cabrero-Antonino, J. R.; Alberico, E.; Drexler, H. J.; Baumann, W.; Junge, K.; Junge, H.; Beller, M. ACS Catal. 2016, 6 , 47. (e) Younus, H. A.; Su, W.; Ahmad, N.; Chen, S.; Verpoort, F. $A d v$. Synth. Catal. 2015, 357, 283. (f) John, J. M.; Loorthuraja, R.; Antoniuk, E.; Bergens, S. H. Catal. Sci. Technol. 2015, 5, 1181. (g) Hu, P.; Fogler, E.; Diskin-Posner, Y.; Iron, M. A.; Milstein, D. Nat. Commun. 2015, 6, 6859. (h) Kita, Y.; Higuchi, T.; Mashima, K. Chem. Commun. 2014, 50, 11211. (i) Smith, A. M.; Whyman, R. Chem. Rev. 2014, 114, 5477. (j) Balaraman, E.; Gnanaprakasam, B.; Shimon, L. J. W.; Milstein, D. J. Am. Chem. Soc. 2010, 132, 16756. (k) Ito, M.; Kobayashi, C.; Himizu, A.; Ikariya, T. J. Am. Chem. Soc. 2010, 132, 114145. (1) Ito, M.; Koo, L. W.; Himizu, A.; Kobayashi, C.; Sakaguchi, A.; Ikariya, T. Angew. Chem. Int. Ed. 2009, 48, 1324. (m) Ito, M.; Sakaguchi, A.; Kobayashi, C.; Ikariya, T. J. Am. Chem. Soc. 2007, 129, 290. Carbamate hydrogenation: (n) Balaraman, E.; Gunanathan, C.; Zhang, J.; Shimon, L. J. W.; Milstein, D. Nat. Chem. 2011, 3, 609; Urea hydrogenation: (o) Balaraman, E.; Ben-David, Y.; Milstein, D. Angew. Chem. Int. Ed. 2011, 50, 11702. (p) John, J. M.; Bergens, S. H. Angew. Chem. Int. Ed. 2011, 50, 10377. (q) Takebayashi, S.; John, J. M.; Bergens, S. H. J. Am. Chem. Soc. 2010, 132, 12832.

12) (a) Wambach, T. C.; Lenczyk, C.; Patrick, B. O.; Fryzuk, M. D. Dalton Trans. 2016, 45, 5583. (b) Vicent, C.; Gusev, D. G. ACS Catal. 2016, 6, 3301. (c) Han, Q.; Xiong, X.; Li, S. Catal. Commun. 2015, 58, 85. (d) Malineni, J.; Keul, H.; Möller, M. Macromol. Rapid Commun. 2015, 36, 547. (e) Li, H.; Zheng, B.; Huang, K. W. Coord. Chem. Rev. 2015, 293-294, 116. (f) Langer, R.; Gese, A.; Gesevičius, D.; Jost, M.; Langer, B. R.; Schneck, F.; Venker, A.; Xu, W. Eur. J. Inorg. Chem. 2015, 696. (g) Gunanathan, C.; Milstein, D. Chem. Rev. 2014, 114, 12024. (h) Malineni, J.; Merkens, C.; Keul, H.; Möller, M. Catal. Commun. 2013, 40, 80.

13) (a) Hu, P.; Ben-David, Y.; Milstein, D. J. Am. Chem. Soc. 2016, 138 , 6143. (b) Bielinski, E. A.; Förster, M.; Zhang, Y.; Bernskoetter, W. H.; Hazari, N.; Holthausen, M. C. ACS Catal. 2015, 5, 2404. (c) Malineni, J.; Keul, H.; Möller, M. Dalton Trans. 2015, 44, 17409. (d) Hu, P.; Diskin-Posner, Y.; Ben-David, Y.; Milstein, D. ACS Catal. 2014, 4, 2649. (e) Choi, J.-H.; Heim, L. E.; Ahrens, M.; Prechtl, M. H. G. Dalton Trans. 2014, 43, 17248. (f) Rodríguez-Lugo, R. E.; Trincado, M.; Vogt, M.; Tewes, F.; Santiso-Quinones, G.; Grützmacher, H. Nat. Chem. 2013, 5, 342. (g) Nielsen, M.; Alberico, E.; Baumann, W.; Drexler, H.-J.; Junge, H.; Gladiali, S.; Beller, M. Nature 2013, 495, 85. (h) Balaraman, E.; Khaskin, E.; Leitus, G.; Milstein, D. Nat. Chem. 2013, 5, 122. (i) Alberico, E.; Sponholz, P.; Cordes, C.; Nielsen, M.; Drexler, H. J.; Baumann, W.; Junge, H.; Beller, M. Angew. Chem. Int. Ed. 2013, 52, 14162

14) (a) $\mathrm{Hu}, \mathrm{P}$; Ben-David, Y.; Milstein, D. Angew. Chem. Int. Ed. 2016, 55, 1061. (b) Nirmala, M.; Viswanathamurthi, P. J. Chem. Sci. 2016, 128, 9. (c) Selvamurugan, S.; Ramachandran, R.; Prakash, G.;
Viswanathamurthi, P.; Malecki, J. G.; Endo, A. J. Organomet. Chem. 2016, 803, 119. (d) Xie, X.; Huynh, H. V. ACS Catal. 2015, 5, 4143. (e) Kim, K.; Kang, B.; Hong, S. H. Tetrahedron 2015, 71, 4565. (f) Oldenhuis, N. J.; Dong, V. M.; Guan, Z. Tetrahedron 2014, 70, 4213. (g) Saha, B.; Sengupta, G.; Sarbajna, A.; Dutta, I.; Bera, J. K. J. Organomet. Chem. 2014, 771, 124. (h) Hasanayn, F.; Harb, H. Inorg. Chem. 2014, 53, 8334. (i) Gunanathan, C.; Milstein, D. Top. Organomet. Chem. 2011, 37, 55. (j) Pattabiraman, V. R.; Bode, J. W. Nature 2011, 480, 471.

15) (a) Kossoy, E.; Diskin-Posner, Y.; Leitus, G.; Milstein, D. Adv. Synth. Catal. 2012, 354, 497. (b) Gunanathan, C.; Shimon, L. J. W.; Milstein, D. J. Am. Chem. Soc. 2009, 131, 3146.

16) (a) Wang, Q.; Wu, K.; Yu, Z. Organometallics 2016, 35, 1251. (b) Jumde, V. R.; Gonsalvi, L.; Guerriero, A.; Peruzzini, M.; Taddei, M. Eur. J. Org. Chem. 2015, 2015, 1829. (c) Wang, D.; Zhao, K.; Yu, X.; Miao, H.; Ding, Y. RSC Adv. 2014, 4, 42924. (d) Musa, S.; Ackermann, L.; Gelman, D. Adv. Synth. Catal. 2013, 355, 3077. (e) Dowson, G. R. M.; Haddow, M. F.; Lee, J.; Wingad, R. L.; Wass, D. F. Angew. Chem. Int. Ed. 2013, 52, 9005. (f) Satyanarayana, P.; Reddy, G. M.; Maheswaran, H.; Kantam, M. L. Adv. Synth. Catal. 2013, 355, 1859. (g) Chang, X.; Chuan, L. W.; Yongxin, L.; Pullarkat, S. A. Tetrahedron Lett. 2012, 53, 1450. (h) Liao, S.; Yu, K.; Li, Q.; Tian, H.; Zhang, Z.; Yu, X.; Xu, Q. Org. Biomol. Chem. 2012, 10, 2973. (i) Obora, Y.; Anno, Y.; Okamoto, R.; Matsu-ura, T.; Ishii, Y. Angew. Chem. Int. Ed. 2011, 50, 8618. (j) Kose, O.; Saito, S. Org. Biomol. Chem. 2010, 8, 896. (k) Chaudhari, C.; Siddiki, S. M. A. H.; Shimizu, K. Top. Catal. 2014, 57, 1042. (1) Miura, T.; Kose, O.; Li, F.; Sun, K.; Saito, S. Chem. Eur. J. 2011, 17, 11146. (m) Gabriëls, D.; Hernández, W. Y.; Sels, B.; Van Der Voort, P.; Verberckmoes, A. Catal. Sci. Technol. 2015, 5, 3876.

17) (a) Mukherjee, A.; Nerush, A.; Leitus, G; Shimon, L. J. W; Ben David, Y.; Espinosa Jalapa, N. A.; Milstein, D. J. Am. Chem. Soc. 2016, 138, 4298. (b) Sindhuja, E.; Ramesh, R. Tetrahedron Lett. 2014 55, 5504. (c) Saha, B.; Wahidurrahaman, S. M.; Daw, P.; Sengupta, G.; Bera, J. K. Chem. Eur. J. 2014, 20, 6542. (d) Musa, S.; Fronton, S.; Vaccaro, L.; Gelman, D. Organometallics 2013, 32, 3069. (e) Zhang, G.; Hanson, S. K. Org. Lett. 2013, 15, 650. (f) Jin, X.; Liu, Y.; Lu, Q; Yang, D.; Sun, J.; Qin, S.; Zhang, J.; Shen, J.; Chu, C.; Liu, R. Org. Biomol. Chem. 2013, 11, 3776

18) (a) Yang, Y.; Qin, A.; Zhao, K.; Wang, D.; Shi, X. Adv. Synth. Catal. 2016, 358, 1433. (b) Chang, Y. H.; Tanigawa, I.; Taguchi, H. O.; Takeuchi, K.; Ozawa, F. Eur. J. Inorg. Chem. 2016, 2016, 754. (c) Marichev, K. O.; Takacs, J. M. ACS Catal. 2016, 6, 2205. (d) Rösler, S.; Ertl, M.; Irrgang, T.; Kempe, R. Angew. Chem. Int. Ed. 2015, 54, 15046. (e) Pingen, D.; Vogt, D. Catal. Sci. Technol. 2014, 4, 47. (f) Balaraman, E.; Srimani, D.; Diskin-Posner, Y.; Milstein, D. Catal. Lett. 2014, 145, 139. (g) Ruch, S.; Irrgang, T.; Kempe, R. Chem. Eur. J. 2014, 20, 13279. (h) Yamaguchi, K.; He, J.; Oishi, T.; Mizuno, N. Chem. Eur. J. 2010, 16, 7199. (i) Yan, Q.; Wang, Q.; Yu, Z. Chem. Soc. Rev. 2015, 44, 2305. (j) Kawahara, R.; Fujita, K.; Yamaguchi, R. Adv. Synth. Catal. 2011, 353, 1161. (k) Yamada, Y. M. A.; Ohta, H.; Yuyama, Y.; Uozumi, Y. Synthesis 2013, 45, 2093

19) (a) Zhao, Y.; Foo, S. W.; Saito, S. Angew. Chem. Int. Ed. 2011, 50, 3006. (b) Du, Y.; Foo, S. W.; Saito, S. Chem. Eur. J. 2011, 17, 12262. (c) Highlighted in: Bähn, S.; Imm, S.; Neubert, L.; Zhang, M.; Neumann, H.; Beller, M. Chem CatChem 2011, 3, 1853. (d) Emer, E.; Sinisi, R.; Capdevila, M. G.; Petruzziello, D.; Vincentiis, F. D.; Cozzi, P. G. Eur. J. Org. Chem 2011, 647. Allylic substitution: (e) Banerjee, D.; Junge, K.; Beller, M. Angew. Chem. Int. Ed. 2014, 53, 13049. (f) Lafrance, M.; Roggen, M.; Carreira, E. M. Angew. Chem. Int. Ed. 2012, 51, 3470. (g) Ohshima, T.; Mashima, K. J. Synth. Org. Chem., Jpn. 2012, 70, 1145. (h) Yamashita, Y.; Gopalarathnam, A.; Hartwig, J. F. J. Am. Chem. Soc. 2007, 129, 7508. (i) Ozawa, F.; Okamoto, H.; Kawagishi, S.; Yamamoto, S.; Minami, T.; Yoshifuji, M. J. Am. Chem. Soc. 2002, 124, 10968.

20) Miura, T.; Held, I. E.; Oishi, S.; Naruto, M.; Saito, S. Tetrahedron Lett. 2013, 54, 2674

21) Saito, S.; Noyori, R.; Miura, T; Held, I.; Suzuki, M.; Iida, K.; Takada, Y. PCT/JP2012/51373(WO/2012/102247)

22) (a) Iida, K.; Miura, T.; Ando, J.; Saito, S. Org. Lett. 2013, 15, 1436. (b) Highlighted in: Schranck, J.; Tlili, A.; Beller, M. Angew. Chem. Int. Ed. 2013, 52,7642

23) (a) Ghose, A. K.; Viswanadhan, V. N.; Wendoloski, J. J. J. Comb. Chem. 1999, 1, 55. (b) Bemis, G. W.; Murcko, M. A. J. Med. Chem. 1999, 42, 5095. (c) Carey, J. S.; Laffan, D.; Thomson, C.; Williams, M T. Org. Biomol. Chem. 2006, 4, 2337. and references cited therein. (d) Burk, R. M.; Woodward, D. F. Drug Dev. Res. 2007, 68, 147. 
24) (a) Beckwith, A. L. J. in The Chemistry of Amides, Zabicky, J.; Patai, S. Eds; John Wiley \& Sons: London, 1970, pp 73-185. (b) Ishihara, K.; Ohara, S.; Yamamoto, H. J. Org. Chem. 1996, 61, 4196. (c) Montalbetti, C. A. G. N.; Falque, V. Tetrahedron 2005, 61, 10827. (d) Gunanathan, C.; Ben-David, Y.; Milstein, D. Science 2007, 317, 790. (e) Al-Zoubi, R. M.; Marion, O.; Hall, D. G. Angew. Chem. Int. Ed. 2008, 47, 2876.

25) (a) Oishi, S.; Saito, S. Angew. Chem. Int. Ed. 2012, 51, 5395. (b) Foo, S. W.; Oishi, S.; Saito, S. Tetrahedron Lett. 2012, 53, 5445.

26) At present, $\mathrm{Me}_{2} \mathrm{~N}\left(\mathrm{CH}_{2}\right)_{\mathrm{n}} \mathrm{OH}(\mathrm{n}=6,3,2)$ have been used worldwide as catalysts for the production of poly(urethane) foam: Imabeppu, M.; Kiyoga, K.; Okamura, S.; Shoho, H.; Kimura, H. Cat. Commun. 2009, 10,753 .

27) (a) Olah, G. A. Angew. Chem. Int. Ed. 2005, 44, 2636. (b) Olah, G. A.; Goeppert, A.; Prakash, G. K. S. J. Org. Chem. 2009, 74, 487.

28) (a) Whitesides, G. M.; Hackett, M.; Brainard, R. L.; Lavalleye, J.-P. P. M.; Sowinski, A. F.; Izumi, A. N.; Moore, S. S.; Brown, D. W.; Staudt, E. M. Organometallics 1985, 4, 1819. (b) Jaska, C. A.; Manners, I. J. Am. Chem. Soc. 2004, 126, 9776. (c) O, W. W. N.; Lough, A. J.; Morris, R. H. Chem. Commun. 2010, 46, 8240.

29) (a) Zhang, J.; Balaraman, E.; Leitus, G.; Milstein, D. Organometallics 2011, 30, 5716. (b) Ohkuma, T.; Koizumi, M.; Muñiz, K.; Hilt, G.; Kabuto, C.; Noyori, R. J. Am. Chem. Soc. 2002, 124, 6508.

30) (a) García-Paciosa, V.; Jofre-Reche, J. A.; Costab, V.; Colerab, M.; Miguel, M.; Martínez, M. Prog. Org. Coat. 2013, 76, 1484. (b) Arpe, H. J., K. Industrial Organic Chemistry, 5th ed.; Wiley-VCH, 2010; pp 252-255.

31) Abe, T.; Haga, T.; Negi, S.; Morita, Y.; Takayanagi, K.; Hamamura, K. Tetrahedron 2001, 57, 2701.

32) (a) Shin, W. K.; Kang, D.; An, D. K. Bull. Korean Chem. Soc. 2014, 35, 2169. (b) Jeon, A. R.; Kim, M. E.; Park, J. K.; Shin, W. K.; An, D. K. Tetrahedron 2014, 70, 4420. (c) Muraki, M.; Mukaiyama, T. Chem. Lett. 1975, 1, 875.

33) (a) Rawat, A. S.; Pande, S.; Bhatt, N.; Kharatkar, R.; Belwal, C.; Vardhan, A. Org. Process Res. Dev. 2013, 17, 1617. (b) Niphade, N.; Mali, A.; Jagtap, K.; Ojha, R. C.; Vankawala, P. J.; Mathad, V. T. Org. Process Res. Dev. 2008, 12, 731. (c) Elati, C. R.; Kolla, N.; Chalamala, S. R.; Vankawala, P. J.; Sundaram, V.; Vurimidi, H.; Mathad, V. T. Synth. Commun. 2006, 36, 169 .

34) Ir and/or Ru: Recent examples: (a) Onodera, G.; Nishibayashi, Y.; Uemura, S. Angew. Chem. Int. Ed. 2006, 45, 3819. (b) Viciano, M.; Sanaú, M.; Peris, E. Organometallics 2007, 26, 6050. (c) Gnanamgari, D.; Leung, C. H.; Schley, N. D.; Hilton, S. T.; Crabtree, R. H.; Org. Biomol. Chem. 2008, 6, 4442. (d) Gnanamgari, D.; Sauer, E. L. O.; Schley, N. D.; Butler, C.; Incarvito, C. D.; Crabtree, R. H. Organometallics 2009, 28, 321.

35) Alonso, F.; Riente, P.; Yus, M. Eur. J. Org. Chem. 2008, 4908.

36) Kwon, M. S.; Kim, N.; Seo, S. H.; Park, I. S.; Cheedrala, R. K.; Park, J. Angew. Chem. Int. Ed. 2005, 44, 6913.

37) Shimizu, K.; Sato, R.; Satsuma, A. Angew. Chem. Int. Ed. 2009, 48, 3982.

38) Cho, C. S.; Ren, W. X.; Yoon, N. S. J. Mol. Catal. A: Chem. 2009, 299, 117.

39) Yang, J.; Liu, X.; Meng, D.-L.; Chen, H.-Y.; Zong, Z.-H.; Feng, T.-T.; Sun, K. Adv. Synth. Cat. 2012, 354, 328.

40) Kim, S.; Bae, S. W.; Lee, J. S.; Park, J. Tetrahedron 2009, 65, 1461.

41) Allen, L. J.; Crabtree, R. H. Green Chem. 2010, 12, 1362.

42) (a) Martínez, R.; Ramón, D. J.; Yus, M. J. Org. Chem. 2008, 73, 9778. (b) Mierde, H. V.; Voort, P. V. D.; Verpoort, F. Tetrahedron Lett. 2008, 49,6893 .

43) (a) Noyori, R.; Saito, S.; Naka H.; Kose, O.; Ando, J. JP 2011-184336; (b) Noyori, R.; Saito, S.; Naka H.; Kose, O.; Ando, J. JP 2011-184338.

44) (a) Jurczak, J.; Golebiowski, A. Chem. Rev. 1989, 89, 149. (b) Sardina, F. J.; Rapoport, H. Chem. Rev. 1996, 96, 1825. (c) Gryko, D.; Chalko, J.; Jurczak, J. Chirality 2003, 15, 514.

45) (a) Badrinarayanan, S.; Sperry, J. Org. Biomol. Chem. 2012, 10, 2126. (b) Badrinarayanan, S.; Sperry, J. Synlett 2011, 2339.

46) Taguchi, K.; Sakaguchi, S.; Ishii, Y. Tetrahedron Lett. 2005, 46, 4539.

47) Michlik, S.; Kempe, R. Nat. Chem. 2013, 5, 140.

48) Srimani, D.; Ben-David, Y.; Milstein, D. Angew. Chem. Int. Ed. 2013, 52,4012 .

49) Zhang, M.; Neumann, H.; Beller, M. Angew. Chem. Int. Ed. 2013, 52, 597.

50) (a) Michlik, S.; Kempe, R. Angew. Chem. Int. Ed. 2013, 52, 6326. (b) Srimani, D.; Ben-David, Y.; Milstein, D. Chem. Commun. 2013, 49, 6632 .

51) (a) Stanton, M. G.; Gagné, M. R. J. Am. Chem. Soc. 1997, 119, 5075. (b) Stanton, M. G.; Allen, C. B.; Kissling, R. M.; Lincoln, A. L.; Gagné, M. R. J. Am. Chem. Soc. 1998, 120, 5981 and references cited therein. (c) Kissling, R. M.; Gagné, M. R. J. Org. Chem. 2001, 66, 9005. (d) Pospisil, P. J.; Wilson, S. R.; Jacobsen, E. N. J. Am. Chem Soc. 1992, 114, 7585. (e) Gruver, J. M.; Liou, L. R.; McNeil, A. J.; Ramirez, A.; Collum, D. B. J. Org. Chem. 2008, 73, 7743. (f) De Vries, T. S.; Goswami, A.; Liou, L. R.; Gruver, J. M.; Jayne, E.; Collum, D. B. J. Am. Chem. Soc. 2009, 131, 13142 and references cited therein.

52) Graul, A.; Castañer, J. Drugs Future 1997, 22, 956.

53) (a) Gürdere, M. B.; Budak, Y.; Ceylan, M. Asian J. Chem. 2008, 20 , 1425. (b) Kuo, W.-J.; Chen, Y.-H.; Jeng, R.-J.; Chan, L.-H.; Lin, W.-P.; Yang, Z.-M. Tetrahedron 2007, 63, 7086. (c) Ban, I.; Sudo, T.; Taniguchi, T.; Itami, K. Org. Lett. 2008, 10, 3607. (d) Feng, X.; Tong, B.; Shen, J.; Shi, J.; Han, T.; Chen, L.; Zhi, J.; Lu, P.; Ma, Y.; Dong, Y J. Phys. Chem. B 2010, 114, 16731. (e) Liao, Q.; Zhang, L.; Wang, F.; Li, S.; Xi, C. Eur. J. Org. Chem. 2010, 5426.

54) Donohoe, T. J.; Race, N. J.; Bower, J. F.; Callens, C. K. A. Org. Lett. 2010, 12, 4094 


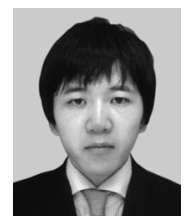

Yuki Takada, born in 1989 in Mie, Japan, is a graduate student at Graduate School of Science, Nagoya University. He received his bachelor's degree and master's degree from Nagoya University and is now seeking his doctoral degree under the guidance of Professor Susumu Saito at Nagoya University. He obtained Research Fellowships for Young Scientists from JSPS (2014). During the doctoral course, he was educated at the Georgia Institute of Technology in US as a visiting scholar with Professor Christopher W. Jones (2015-2016).

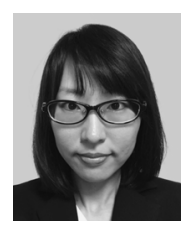

Megumi Iida (maiden name: Suzuki), born in 1985 at Aichi, Japan, is a research scientist at New Products Research Laboratory, Toagosei Co., Ltd. She obtained her bachelor's degree (2009) and master's degree of Science (2011) from Nagoya University under the supervision of Professor Susumu Saito. Her research interest is polymer chemistry.

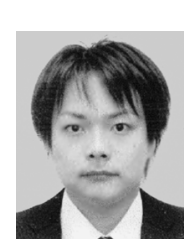

Kazuki Iida, born in 1988 at Nagano, Japan, is a research scientist at the Future Technology Management Center, NGK INSULATORS, LTD. He obtained his bachelor's degree (2011) and master's degree of Science (2013) from Nagoya University under the supervision of Professor Susumu Saito. His current research interest is in the development of new functional inorganic materials at NGK.

Takashi Miura, born in 1986 at Aichi, Japan, is a researcher of DIC Corporation. He obtained his bachelor's degree (2010), master's degree (2012) and doctoral degree of Science (2015) from Nagoya University (NU) under the supervision of Professor Susumu Saito.

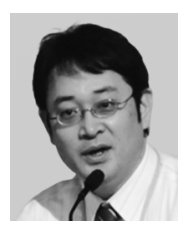

Susumu Saito, born in 1969 at Okayama, Japan, is a professor of Graduate School of Science, Nagoya University. He obtained his bachelor's degree (1991), master's degree (1993) and doctoral degree of Engineering (1998) from Nagoya University (NU) under the supervision of Professor Hisashi Yamamoto. During this time he attended Prof. E. Jacobsen's group at Harvard, USA as a Visiting Researcher (1994). His first academic position was Assistant Professor at the Graduate School of Engineering, NU (1995), and he became Associate Professor of Institute for Advanced Research (IAR) \& Graduate School of Science, NU (2002) and promoted to a Full Professor and IAR Fellow (2015). He was an Asian Core Program Lecturer awarded from China (2009) and from Taiwan (2009), and invited as a Visiting Associate Professor of Institute for Chemical Research, Kyoto University (2004) and Visiting Lecturer of Institute for Materials Chemistry and Engineering, Kyushu University (2009). 